\title{
BIENES, PROPIEDADES, TÍTULOS LUCRATIVOS Y ONEROSOS DE LOS MORISCOS DE SEGORBE: SU ECO DURANTE EL TRIENIO POSTERIOR A LA EXPULSIÓN (1610-1612) ${ }^{1}$
}

\author{
PABlo PÉRez García y BlanCA EsPuig CORELL \\ Universitat de València
}

Fecha de recepción: septiembre 2008

Fecha de aceptación: diciembre 2008

\section{EL DÍA DESPUÉS}

La de Segorbe había sido una de las aljamas valencianas que más quebraderos de cabeza había ocasionado a la Corona en el pasado. En un tiempo algo remoto ya -1526- el rebelde Selim Al-Mansur y sus hijos habían escapado de las manos del emperador Carlos en Espadán y se habían refugiado en el Arrabal de Segorbe, donde estuvieron escondidos hasta su captura y ejecución ${ }^{2}$. Más recientemente -1568/1585el nombre de la ciudad y de su aljama continuaba resonando en la Corte como la patria de «grandes conspiradores». De las andanzas de los moriscos segorbinos Lorenzo Benazar y Juan Izquierdo el Cojo -en efecto- cabía temer lo peor ${ }^{3}$. La reacción de las

1. Este trabajo forma parte del proyecto de investigación titulado El gobierno, la guerra y sus protagonistas en los reinos mediterráneos de la Monarquía Hispánica (Ref. HAR2008-00512) dirigido por el Prof. Rafael Benítez Sánchez-Blanco.

2. PARdo Molero, Juan Francisco: La guerra de Espadán (1526). Una cruzada en la Valencia del Renacimiento, Segorbe, 2001, pág. 103.

3. PÉREZ GARCÍA, Pablo: Segorbe a través de su historia. Despegue económico y cambio social en la capital del Alto Palancia, Segorbe, 1998, págs. 217-218. Véase también CARRASCO, Raphaël: «Historia de una represión. Los moriscos y la Inquisición de Valencia (1566-1620)», La Monarchie Catholique et les Morisques (1520-1620). Études franco-espagnoles, Montpellier, 2005, pág. 106. 
aljamas de la comarca de Segorbe ante el decreto de expulsión resultaba tan potencialmente amenazadora que el rey Felipe III puso todo su empeño en cortar todos los hilos que habrían permitido a los moriscos organizar una revuelta de consecuencias tan imprevisibles como la de $1526^{4}$. Por todo ello parece pertinente subrayar, al iniciar nuestro trabajo, que ningún indicio documental o cronístico -Escolano y Diago, principalmente- permite sospechar que los moriscos segorbinos adoptaran otra actitud que la resignación ante las noticias publicadas el 22 de septiembre de 1609 al toque guerrero de los timbales y las chirimías de los pregoneros reales.

Aquel día debió quedar grabado a fuego en la memoria de los valencianos ${ }^{5}$. La disposición era clara: con pequeñísimas excepciones todos los moriscos debían ser conducidos hasta la costa para ser embarcados con destino todavía incierto. ¿Podría alguien haber conocido esta orden y haber continuado conservando la serenidad? El nerviosismo debió apoderarse de muchos: los moriscos sin saber todavía bien a qué carta quedarse, y los cristianos viejos expectantes ante lo que todavía no se sabía si podía ser un festín o una hambruna. Los lazos de solidaridad entre los moriscos - tradicionalmente intensos- debieron estrecharse todavía más ante aquel destino trágico que estaban llamados a compartir. Durante la semana siguiente a la publicación de la orden de extrañamiento, los moriscos intentaron malvender todas sus propiedades. Nuevo golpe; conocida la orgía de ventas, el Marqués de Caracena prohibió este tipo de operaciones y limitó la obtención de dinero líquido a la venta de pequeñas propiedades $(1-\mathrm{X}-1609)^{6}$.

Los moriscos comenzaron a deshacerse entonces de sus enseres y herramientas, de sus muebles, del pequeño ajuar de sus esposas e hijas, de algunas joyas - hasta los clavos y los cerrojos de sus casas se vieron comprometidos ${ }^{7}$ - conscientes de que su equipaje tenía que ser ligero y precisados de todo el dinero que pudieran reunir. No quedó una sola casa en el Arrabal que no precisase después algún tipo de reparación. Sus nuevos inquilinos cristiano-viejos no hubieran ocupado ninguna de ellas si los desperfectos no se hubieran descontado del precio del alquiler ${ }^{8}$. En algún caso, las obras

4. Los accesos a la Sierra de Espadán estaban taponados desde finales de agosto o principios de septiembre por orden de D. Agustín Mexía. LAPEYRE, Henri: Geografía de la España morisca, Valencia, 1986, p. 67.

5. Aunque la bibliografía sobre el XVII valenciano y los moriscos es abundante, citamos exclusivamente dos obras capitales. CASEY, James: El Reino de Valencia en el siglo XVII, Madrid, 1983; BENÍTEZ SÁNCHEZBLANCO, Rafael: Heroicas decisiones. La Monarquía Católica y los moriscos valencianos, Valencia, 2001.

6. Danvila Collado, Manuel: La expulsión de los moriscos españoles. Conferencias pronunciadas en el Ateneo de Madrid, Valencia, 2007, apéndice documental, pág. 348.

7. Una de las primeras preocupaciones de la administración del expolio del Ducado de Segorbe fue precisamente la desaparición de las cerraduras de las casas. Que las viviendas moriscas hubiera quedado abiertas no sólo propiciaba los pequeños hurtos -tejas, baldosas, rejas, ventanas, etc.- sino también facilitaba el rápido deterioro de los inmuebles. Muchas de los cerrojos debieron venderse, pero a buen seguro otros acompañaron a sus dueños en su viaje hasta Orán con la esperanza de ser instalados en el primer refugio que encontraran. ARV: Real Audiencia. Procesos. Parte Primera. Letra A, exp. 887, fols. 2 r-3 r (31-III1610). ARV: Maestre Racional, exp. 10.123, fol. 13 v.

8. ARV: Maestre Racional, exp. 10.123, fol. $13 \mathrm{v}$. 
necesarias llegaron a superar las 100 libras $^{9}$. Los moriscos segorbinos dispusieron aproximadamente de 5 semanas para poner en un orden razonable sus asuntos, empaquetar sus pertenencias y ponerse en marcha hacia la costa. La despedida se produjo el día 2 de noviembre de $1609^{10}$. Unas 350 familias -según el recuento del Marqués de Caracena ${ }^{11}$ - iniciaron el camino hacia el exilio definitivo entre llantos y expresiones de dolor, y quién sabe si acompañados un trecho por amigos y vecinos de la ciudad de Segorbe.

El decreto de expulsión había previsto algunas excepciones. Sin embargo, sabemos muy poco - apenas nada- de quienes permanecieron en Segorbe. Sobre la identidad de un anciano de unos 70 años de edad al que el notario Juan Miguel Perdiguer llamaba Nicolás Pons, alias Benazar ${ }^{12}$, y los administradores del expolio Nicolás Benazar, alias Pons, se organizó una notable controversia que acabó dirimiendo la Real Audiencia de Valencia el 7 de septiembre de $1611^{13}$.. El notario proclamaba que Nicolás era cristiano viejo, mientras que Mateo Bosch y Alonso de Guevara sostenían que lo era nuevo. La cuestión -en definitiva- resultaba indiferente, pues Pons-Benazar había sido autorizado a quedarse en Segorbe no sólo por las autoridades civiles, sino también por la eclesiásticas y por la propia Inquisición ${ }^{14}$. Nicolás había vivido siempre en el Arrabal de Segorbe. Había tomado por esposa a la morisca Juana Razín y había tenido una hija, llamada Jerónima. El día de su boda con Alonso Acén -9 de febrero de 1586- Nicolás Benazar donó a la pareja gran parte de sus bienes, entre ellos el dominio útil de varias parcelas de tierra en la partida del Censal que pertenecían a la Cartuja de Valdecristo ${ }^{15}$. Jerónima y Alonso tuvieron varios hijos, pero ninguno de ellos sobrevivió a su madre, fallecida el 29 de junio de 1598 tras 30 años de vida en común con Acén ${ }^{16}$. Las rela-

9. Una visura realizada por los canteros Pedro de Rivas y Bautista Simón, y por el albañil Pedro de Armañán, preveía un gasto superior a las 100 libras en las reparaciones necesarias de las casas de Juan Taher y de Jerónimo Razín en el Arrabal. ARV: Real Audiencia. Procesos. Parte Primera. Letra A, exp. 917, fols. 1 r-5 r (11-I-1611).

10. Hasta ahora sabíamos por el libro de Henri Lapeyre (pág. 75, nota 45) que los moriscos de Vall d’Uxó, Segorbe y Geldo habían sido embarcados en el puerto de Moncofa, y que los segorbinos lo habían sido antes del día 5 de noviembre. La fecha exacta de la partida de Segorbe, el 2 de noviembre de 1609, ha podido ser establecida gracias a la reclamación presentada por Alonso de Guevara ante la Real Audiencia valenciana (17-XII-1613). ARV: Real Audiencia. Procesos. Parte Primera. Letra A, exp. 985, fol. 1 r.

11. PÉreZ GARCÍA, P.: Op. cit., pág. 375. Es probable que el número de familias moriscas de Segorbe no fuera tan elevado en realidad. El cómputo se llevó a cabo por casas y cerca de una veintena estaban ocupadas por viudas maduras o ancianas sin hijos o cuyos hijos se habían emancipado ya.

12. Las variedades gráficas que presenta este apellido en la documentación son numerosas: Ben[n]as[s]ar,

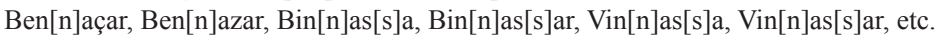

13. ARV: Real Audiencia, Procesos. Parte Primera. Letra A, exp. 928, fols. 38 r-40 v.

14. En este sentido, Perdiguer disponía de dos documentos firmados por el obispo Ginés de Casanova el 17 de febrero de 1610 y por José del Olmo, escribano del Santo Oficio de Valencia, el 17 de marzo del mismo año. Ibidem, fols. $30 \mathrm{r}-30 \mathrm{v}$.

15. La donación fue protocolizada por el notario Francisco Teruel. Ibidem, fols. $10 \mathrm{r}-11 \mathrm{v}$.

16. Los gastos del entierro de Jerónima Benazar se elevaron a 3 libras, 9 sueldos y 3 dineros. Ibídem, fol. $36 \mathrm{v}$. 
ciones entre suegro y su yerno debieron ser excelentes, pues tras la muerte de su hija, Nicolás no sólo no reclamó la devolución de la propiedad, sino incluso pagó varias deudas contraídas por Alonso ${ }^{17}$. Sólo cuando Acén fue forzado a abandonar Segorbe, Nicolás Benazar volvió a ocuparse de sus antiguas propiedades y a pagar los censos anuales que, como a señor útil, correspondían a Valdecristo.

En aquel momento Nicolás era un anciano enfermo cuyo estado de salud debió agravarse durante los dos meses - enero y febrero de 1610 - de intenso frío que tuvo que pasar en Valencia a merced de la Inquisición. Quién sabe si de manera altruista, con la esperanza de heredar su patrimonio o por algún otro motivo, Nicolás Benazar fue acogido en casa del notario Perdiguer y atendido hasta el mismo día de su fallecimiento, el 26 de junio del año 1611. Durante los 4 últimos meses de su vida, Nicolás estuvo postrado en el lecho sin poder levantarse. Era atendido a diario por una mujer que lo limpiaba y curaba sus llagas. Cada vez que concluía el mes, el notario Perdiguer le hacía comprar una sábana y una camisa nueva, pues las anteriores estaban podridas ${ }^{18}$. Benazar había dictado su último testamento el 17 de enero de 1611 ante el notario Miguel Jerónimo García ${ }^{19}$. Por descontado, legaba todos sus bienes y posesiones a Perdiguer. Pero bastó que se hiciera pública la herencia para que los administradores Bosch y Guevara cayeran sobre Perdiguer y sobre la memoria de Nicolás Benazar, contra la que lanzaron todo tipo de baldones: haberse apropiado fraudulentamente de bienes que ya no eran suyos, haber perdido sus propiedades por haberlas donado a un morisco expulso, ser él mismo un morisco... Perdiguer, que no estaba dispuesto a perder el legado de Benazar y mucho menos el dinero que había invertido en su manutención y cuidado, apeló a la Real Audiencia (27-VI-1611) y ganó el pleito al expolio merced a una sentencia firmada por los oidores Sisternes, Mayor, Blasco, León y Roig (7-IX-1611).

La pequeña historia de Nicolás Benazar y Juan Miguel Perdiguer -escasamente representativa por su singularidad, aunque extraordinaria y apasionante en su hilo argumental-ilustra bien la complejidad de las relaciones entre cristianos viejos y moriscos en Segorbe. En la capital del Ducado del mismo nombre - como en tantas otras grandes poblaciones valencianas: Xàtiva, Alzira, Gandia, etc.- cristianos nuevos y viejos compartían vecindazgo y afanes. Formaban dos comunidades administrativas separadas - Consell y Aljama- pero la vida de ambas estaba fuertemente interrelacionada ${ }^{20}$. Los cristianos viejos - unas 700 familias-duplicaban a los moriscos de Segorbe ${ }^{21}$. No obs-

17. Ibidem, fol. $38 \mathrm{r}$.

18. Ibidem, fol. $36 \mathrm{r}$.

19. Ibidem, fol. $1 \mathrm{r}$.

20. Los libros de la administración del secuestro de Segorbe (1575-1618) permiten documentar que los cristianos arrendaban con toda normalidad regalías dentro del arrabal morisco - como el llamado horno nuevo-y los moriscos -individualmente o formando asociaciones mercantiles con otros moriscos o con cristianos viejos- arrendaban propiedades dominicales y regalías fuera del arrabal.

21. Sobre la demografía de Segorbe y la comarca del Alto Palancia, vide GuERRERO CAROT, Francisco: El Palancia: nacer y emigrar. La evolución de la población (siglos XVI al XIX), Castellón de la Plana, 2005. 
tante, alrededor de la ciudad, una pequeña constelación de poblaciones bullía repleta de familias moriscas cercana o lejanamente emparentadas con las segorbinas: Cárrica, Geldo, Navajas, Soneja, Sot de Ferrer, Vall de Almonacid, etc ${ }^{22}$. Desde el primer día estuvo claro que el decreto de expulsión iba a convulsionar el conjunto del término municipal segorbino. A decir verdad -no obstante- las expectativas no eran pésimas, al menos desde la óptica de los cristianos viejos. La expulsión abría - de hecho-posibilidades de promoción nunca soñadas a un grupo bastante notable de segorbinos ávidos de propiedades, dispuestos a ensanchar sus explotaciones y a incrementar sus beneficios. La documentación que hemos tenido ocasión de manejar pone de relieve que fueron los propios segorbinos -y no gentes procedentes de otros lugares- quienes se hicieron mayoritariamente con el arrendamiento - primero- y con el establecimiento enfitéutico - poco después- de las propiedades expoliadas a los moriscos.

Esto -claro- en el mejor de los casos, porque del mismo modo que los documentos reiteran una y otra vez los nombres de un centenar y medio largo de segorbinos que pudieron aprovechar aquellas circunstancias extraordinarias, también nos permiten atisbar el lado menos brillante e -incluso- más sórdido de esta situación irrepetible. Nadie permaneció indiferente ante los acontecimientos y menos aún el consell, interesado como estaba en la agregación a la ciudad del arrabal de Segorbe y en evitar a toda costa los pequeños hurtos, desmanes y asaltos dentro de su recinto ${ }^{23}$.

No fueron pocos los labradores que intentaron modificar en beneficio propio las lindes de sus propiedades, incorporando parte de la tierra de sus vecinos moriscos. Los encargados de la custodia y administración de las propiedades abandonadas por los moriscos tuvieron que emplearse a fondo para adquirir un conocimiento más o menos preciso de las heredades, detectar los movimientos sospechosos, evitar que las cosechas que habían quedado en los campos fuesen robadas y disuadir a los defraudadores de cualquier intento de apropiación indebida. No menos de 11 personas intervinieron en la vigilancia más o menos permanente del agro segorbino entre septiembre de 1609 y los primeros meses de 1610: Juan Capilla -encargado del inventario de los viñedos de la partida de Amara ${ }^{24}$ - Baltasar Hervás - que, a su vez, dirigió un grupo indeterminado de veedores ${ }^{25}$ - Alejo Benafer y Dionisio Gómez - cuyos trabajos se centraron en las partidas de la huerta segorbina ${ }^{26}$ - Andrés Sánchez el mayor, Vicente

22. PÉReZ GARCÍA, P.: Op. cit., pág. 375.

23. Por lo que sabemos, la ciudad de Segorbe bien pudo invertir cerca de 600 libras en la custodia del antiguo arrabal morisco desde finales del año 1609 hasta principios del año 1613. Varios clavarios de la ciudad -Luis Escrig, Juan Onofre Estornell y Martín Palomares- así como el ciudadano y administrador del hospital segorbino Vicente Belluga y el prestigioso jurista Juan Bautista Just anduvieron implicados en la vigilancia del arrabal de San Pedro. ARV: Maestre Racional, exp. 9.744, fol. $11 \mathrm{v}$.

24. ARV: Maestre Racional, exp. 10.117, fol. 27 r.

25. Ibidem, fol. $27 \mathrm{v}$.

26. Ibidem, fol. $27 \mathrm{v}$. 
Escrig y 7 colectores de cosechas de los que conocemos el nombre completo de tres -Lorenzo de Godos, Vicente Ibarra y Gregorio Pérez- y el apellido de uno - Aliaga ${ }^{27}$.

Los asentamientos y reasentamientos de los nuevos pobladores cristianos viejos avanzaron - a decir verdad- con bastante celeridad. Aunque es posible que los primeros establecimientos de tierras comenzaran un poco antes, todo parece indicar que la primera gran oleada se desencadenó hacia mediados de $1611^{28}$. Las condiciones para la cesión de tierra -aunque incluían censos en especie en mayor o menor proporción- no parece que fueran muy duras. De hecho, muchos de los nuevos enfiteutas procedentes de poblaciones alejadas de Segorbe todavía no se habían instalado en sus nuevos domicilios del arrabal ni tomado posesión de sus heredades a finales de 1615. Ante esta situación, el comisario real Adrián Bayarte decidió imponer un plazo improrrogable de 3 meses -a contar desde el día 26 de octubre de este año- para conminar a los enfiteutas a domiciliarse, con alguna excepción debida a las especiales dificultades de la repoblación, como podría ser el caso de Algimia y Alfara ${ }^{29}$. El establecimiento de colonos y enfiteutas en Navajas -al parecer- había progresado de una manera óptima. Sin embargo, el éxito económico alcanzado por éstos había sido bastante limitado. La situación más desesperada afectó a aquellos repobladores de Navajas a los que había correspondido en suerte los lotes de tierras situados dentro del término de Segorbe. Para no frustrar aquella repoblación tan delicada, el comisario Bayarte tuvo que tomar la decisión de condonar las deudas contraídas con la clavería del expolio por los colonos más afectados hasta el año 1614 inclusive $^{30}$. Como vemos, los moriscos de la comarca de Segorbe no siempre dejaron tras de sí una estela de ascenso social entre los cristianos viejos que vinieron a llenar el vacío provocado por su expulsión.

\section{LA ADMINISTRACIÓN DEL EXPOLIO DEL DUCADO DE SEGORBE}

La ciudad de Segorbe constituía en 1609 la cabecera de uno de los grandes dominios señoriales del Reino de Valencia. Su valor y rentas probablemente no fueran los

27. Ibídem, fol. 15 v. A estos 11 nombres habría que añadir los de Monserrat Torres, Gaspar Cantell y Francisco Alcahut, designados por el clavario Sebastián Pérez para la vigilancia de los campos y la recolección de los frutos de los moriscos de Geldo, Navajas y el resto del término segorbino. Ibídem, fols. $1 \mathrm{r}-2 \mathrm{v}$.

28. Como veremos en el punto $3^{\circ}$, fue el fiscal del Consejo de Aragón, Dr. Salvador Fontanet -al parecer, a mediados de 1611 - el primero de los delegados regios que se ocupó de la concertación de contratos enfitéuticos con los colonos y repobladores de la comarca de Segorbe. Este tema quedó después en manos de los clavarios del expolio quienes, a su vez, debieron delegar en diferentes abogados y procuradores. Sólo conocemos la identidad de uno de ellos. Se trata del prestigioso abogado Onofre Bartomeu Ginart, abogado de los clavarios Joaquín Larralde y Joaquín Ayerve, que intervino en este tema -al menosdurante el mes de julio del año 1613. ARV: Real Audiencia. Procesos. Parte Primera. Letra A, exp. 961, fol. 2 v. Sobre Ginart o Ginard, véase Graullera SANZ, Vicente: «Una aproximació al llibre jurídic valencià d'época foral», El llibre de dret valencià a l'època foral, Valencia, 2002, pág. 58. Del mismo autor: Juristas valencianos del siglo XVII, Valencia, 2003, págs. 208-209.

29. ARV: Maestre Racional, exp. 10.123, fol. 14 r.

30. Ibidem, fols. $14 \mathrm{r}-14 \mathrm{v}$. 
más elevados de entre todos los señoríos valencianos, pero sus dueños descendían de ramas legítimas y colaterales a la dinastía reinante, y sus posesiones en Valencia, Cataluña y Castilla constituían uno de los más importantes agregados patrimoniales de toda la Monarquía Católica. Durante un siglo desde la erección del Ducado en 1475, Segorbe había poseído 4 señores descendientes todos ellos de Enrique, infante de Castilla, hijo del rey Fernando I y hermano de los también soberanos aragoneses Alfonso V el Magnánimo y Juan II. Su hijo, el infante Fortuna D. Enrique de Aragón, había sido el primer duque de Segorbe, aunque -consciente del rechazo que la impuesta condición señorial provocaba entre los segorbinos- nunca hizo ostentación de su título. D. Alfonso, su hijo -responsable de la victoria de Almenara contra los agermanados, virrey de Valencia (1559-1563) y ejecutor del desarme general de los moriscos valencianos ordenado por Felipe II en 1563- fue el segundo señor de Segorbe ${ }^{31}$.

Sus hijos, Fernando y Francisco Ramón, le sucedieron -uno tras otro- como $3^{\circ}$ y $4^{\circ}$ duques de Segorbe, respectivamente. D. Fernando sobrevivió apenas unos meses a su padre. La vida de su hermano Francisco Ramón se prolongó durante 11 años más. Amante de las letras y de las artes, Francisco de Aragón no desdeñó el ejercicio del gobierno político y de las armas, como lo demuestra su gestión de la crisis -las alteraciones - turolense de 1572. D. Francisco estuvo estrechamente vinculado a las ciudades de Valencia y Segorbe. De hecho, su muerte se produjo en Segorbe, el día de la Ascensión de 1575, mientras contemplaba una justa de cañas y una carrera de sortijas que la ciudad había organizado en su honor en la Plaza del Mercado, justo en la antesala -por así decir- de la morería o Arrabal de Segorbe, a la que se podía acceder desde el mercado a través del Callejón de Sangarrén y del Portal Nuevo ${ }^{32}$.

El fallecimiento del duque Francisco Ramón sin hijos provocó una situación muy delicada y compleja, de consecuencias ciertamente imprevisibles. La ciudad vio la posibilidad de liberarse del yugo señorial e instó de inmediato un proceso judicial de reversión a la Corona. Las hermanas del difunto -no sólo las casadas, como D. ${ }^{\text {J Juana }}$ Folch de Cardona, sino también las solteras Francisca, Beatriz y Magdalena ${ }^{33}$ - comenzaron a pleitear entre sí y contra la viuda del Duque difunto, D. ${ }^{a}$ Ángela de Cárdenas y Velasco. D. Pedro de Aragón, hermano menor de D. Francisco, canónigo-tesorero de la catedral de Segorbe y futuro obispo de Vich y de Jaca, tampoco anduvo absolutamente ajeno a estas controversias patrimoniales. La Corona-como, por otra parte, era su obligación- tuvo que terciar mientras se resolvían los dilemas y las demandas. A finales del año 1575 el rey Felipe II comisionó a D. Francisco de la Caballería como secuestrador real del Ducado de Segorbe ${ }^{34}$. Comenzaba así una largo período de más de

31. PÉreZ García, P.: Op. cit., págs. 195-197.

32. Ibídem, págs. 198-201.

33. La gracia y la belleza de las hijas del Duque de Segorbe fue cantada por Jorge de Montemayor en los versos 153 a 192 de Los siete libros de La Diana (Madrid, 1991), págs. 285-286.

34. El secuestro del Ducado de Segorbe, además de la ciudad y del arrabal del mismo nombre, comprendía las poblaciones de Alcudia y Veo, Ahín, Alfondeguilla, Castrón y Sabdón, Eslida, Fanzara, Geldo, Navajas, Suera Vall d'Uxó y las heredades o masías de Campillo, Rodana y Ruvial. 
40 años, durante el cual la ciudad y el Ducado de Segorbe iban a estar bajo el control de gobernadores, administradores o secuestradores designados por la Corona. Esta etapa no concluiría hasta comienzos del año 1619, con la entrega del Ducado y de su capital a D. Enrique Raimundo Folch de Cardona, nieto y heredero de D. ${ }^{a}$ Juana Folch ${ }^{35}$.

La gestión del secuestro del Ducado de Segorbe fue todo lo compleja y sinuosa que cabría esperar no sólo de la enmarañada estructura jurisdiccional del señorío, sino también del impacto que sobre la misma fueron causando los sucesivos triunfos ante los tribunales de las partes en litigio. Los libros de administración del secuestro repitieron un idéntico y sistemático patrón de ingresos y gastos durante sus 11 primeros años de vigencia (1575-1586). Pero a partir de entonces las Real Audiencia fue ordenando la entrega de la posesión o del usufructo de determinadas propiedades y regalías tanto a D. a Ángela de Cárdenas, cuanto a D. a Juana de Aragón y a sus hermanas, así como a la ciudad de Segorbe. La forzosa renuncia a porciones crecientes de la administración del secuestro obligó a un permanente reacomodo o reestructuración de los libros de contabilidad a partir de 1586. Aunque podríamos singularizar diversas etapas más según los cambios formales y de contenido operados en la documentación del secuestro - 1686$88,1589-97,1598-99,1600-09,1610-19$ - baste señalar ahora que a lo largo de estos 43 largos años, la administración real siempre mantuvo en su poder un núcleo fundamental de ingresos - el llamado Antiguo Patrimonio- que, entre otros ingresos, comprendía la mayor parte de las servidumbres dominicales y de vasallaje de la Aljama morisca.

Durante sus 11 primeros años de vigencia, los libros de administración y contabilidad del secuestro estuvieron divididos - no obstante- en tres grandes apartados: Antiguo Patrimonio, Ciudad de Segorbe y demás poblaciones del Ducado. El primer bloque agrupaba una pequeña serie de derechos jurisdiccionales -tercio diezmo de pan y vino, almudín, trajón, peso y mercado, censos enfitéuticos y luismos, que se completaba, ya al final del expediente, con los ingresos judiciales- más el arrendamiento de los dos hornos de la morería y del alfar. El segundo bloque abarcaba alrededor de una treintena de conceptos - arrendamiento de casas y huertos, principalmente- entre los que se contaban los llamados censales de Segorbe y Geldo y el presente de Navidad. A partir de 1586 -como hemos indicado- la gestión del secuestro comenzó a experimentar modificaciones. Por una parte, el Antiguo Patrimonio comenzó a incorporar algunos ítems nuevos -la pescadería, el burdel, las tiendas de arriba y de abajo del Arrabal, más los ingresos judiciales-y, por otra, la Ciudad de Segorbe fue progresivamente purgada de aquellas propiedades que el magistrado José Pérez de Banyatos decidió poner en manos del consell segorbino y algunos miembros de la familia Folch de Cardona.

Nuevos cambios contables y administrativos se produjeron a lo largo de los años 1586 a 1609, durante el mandato de los secuestradores D. Jerónimo de Vich, D. Diego López de Mendoza y D. Roque Valero Ceverio, y de los clavarios Miguel Rillo, Jaime Asensio, Martín Andrés y Damián Luques. Cuando se conoció el decreto de expulsión de los moriscos, el Antiguo Patrimonio -que ahora comprendía, además de sus com-

35. PÉReZ GARCíA, P.: Op. cit., págs. 227-236. 
ponentes tradicionales, la llamada caseta de encima de la pescadería y los censales de Segorbe ${ }^{36}$ y del Arrabal- había vuelto a perder los ingresos agregados en $1586^{37}$. Éstos habían vuelto a formar una serie aparte el año $1589^{38}$, pero muy pronto volverían a quedar nuevamente unidos a los ingresos del Antiguo Patrimonio. En efecto, a partir del bienio 1611-12, las tiendas, el burdel, la pescadería y las penas y composiciones judiciales quedarán unidas al Antiguo Patrimonio hasta el final del secuestro el año $1619^{39}$. El contenido de estas fuentes permitiría realizar -desde luego- una primera aproximación al impacto que la expulsión de los moriscos pudo haber tenido en la economía segorbina ${ }^{40}$.

Nosotros, sin embargo, no nos serviremos de esta documentación, sino de aquella otra que específicamente fue compuesta para dar cuenta de las propiedades que los moriscos segorbinos se vieron obligados a abandonar el 2 de noviembre de 1609 . Porque, pese a hallarse Segorbe bajo el gobierno de un secuestrador real -el caballero de Montesa D. Roque Valero Ceverio- y disponer de varios clavarios y de un alcaide ${ }^{41}$, el virrey Marqués de Caracena y la Real Audiencia juzgaron necesario no sólo designar autoridades diferentes para hacerse cargo de las propiedades abandonadas por los moriscos, sino también abrir libros de administración y de cuentas separados para lo que sería conocido como Expoli dels moriscos del Ducat de Sogorb ${ }^{42}$. En un primer momento y con carácter de urgencia, Caracena designó a un oidor de la Audiencia, D.

36. Este censal de la ciudad de Segorbe se paga en razón de la cesión de los derechos de herbaje al consell municipal.

37. ARV: Maestre Racional, exp. 9.744 (1609).

38. Esta serie comienza con el expediente 9.737 de la sección Maestre Racional del ARV correspondiente al trienio 1589-91, continúa con el 9.738 (1592-96) y el 9.739 (1597-99), se interrumpe entre 1600 y 1601 y se reanuda con los exps. 9.741 (1602-03), 9.742 (1604), 10.195 (1605), 10.196 (1606), 9.743 (1607), 10.197 (1608), 10.198 (1609), 9.746 (1610), 9.747 (1611) y 9.748 (1612).

39. La serie Antiguo Patrimonio continuará existiendo en solitario durante el trienio 1610-12 [exps. 9.745 y 9.749; el exp. 9.748 (1611) sólo contiene censos enfitéuticos monetarios y luismos] para fundirse con la otra a partir del exp. 9.750 (1613) hasta el último de la serie 9.754 (1617).

40. De más a menos, el impacto de la expulsión se hizo sentir, sobre todo, en el horno viejo de la morería -que ya no volvió a arrendarse, al menos hasta 1618- y la tienda de las nieves, en el arrendamiento del derecho de Almudín - que quedó a reducido a la mitad-y del horno nuevo de la morería -que no se arrendó en 1609 y su precio cayó a menos de una cuarta parte en 1611- en el tercio diezmo del pan y del vino -que, aunque no se percibió en 1610, muy pronto recuperó las cifras anteriores a 1609-en el arrendamiento de los derechos de peso y mercado - que cayó durante algunos años. Los restantes ítems de ingreso del secuestro -alfar, burdel, carnicerías, tiendas de arriba, de abajo y casas encima de la pescadería- apenas parece que fueran afectados con la expulsión de los moriscos.

41. El anterior alcaide, José Valverde de Tovar, había fallecido el 17 de diciembre de 1608. Interinamente fue designado Cristóbal de Cisneros, lugarteniente de capitán de la guardia del Virrey, que ejerció su cargo hasta bien entrado el año 1609. Sin embargo, en septiembre ya se había incorporado el nuevo alcaide titular D. Gil Pérez de Banyatos. Banyatos - que el año 1610 mantuvo un pleito con el Síndico de la ciudad de Segorbe sustanciado por la Real Audiencia- estuvo al frente de la alcaidía, por lo menos, hasta 1617. ARV: Maestre Racional, exps. 9.744, fols. 12 r-12 v y 9.746, fols. s/n (hojas sueltas del final).

42. Los libros del Expolio del Ducado de Segorbe constituyen la base fundamental de nuestro trabajo, según se irá exponiendo en epígrafes posteriores. 
Marco Antonio Sisternes, y a un delegado suyo, D. Juan de Vallterra, como responsables de las medidas a tomar inmediatamente antes e inmediatamente después de la expulsión de los moriscos ${ }^{43}$. Muy poco después de la salida de los moriscos, el Virrey decidió transferir la máxima responsabilidad en la administración del expolio a dos destacados ciutadans segorbinos: Mateo Bosch y Alonso de Guevara. El primero había desempañado ya algunos cargos municipales y muy pronto alcanzaría la condición de baile de Segorbe ${ }^{44}$, mientras que el segundo tenía en su haber la triple condición de ser uno de los más importantes acreedores censalistas de los moriscos ${ }^{45}$, representar a otros acreedores en la misma situación ${ }^{46}$ y ser uno de los máximos damnificados por la expulsión, ya que -desde el primer domingo de agosto del año 1609- tenía arrendado el avituallamiento de carnes de la morería de Segorbe ${ }^{47}$.

La labor de los administradores Bosch y Guevara -bajo cuyas órdenes estuvo D. Juan Valterra durante una pequeñísima temporada- consistía en la supervisión de los bienes y la propiedades embargadas a los moriscos, el arrendamiento de las mismas en tanto se producían las primeras ventas y los primeros contratos enfitéuticos con los nuevos colonos y repobladores, la cosecha de los frutos de las tierras abandonadas, la percepción de las particiones en especie, el cuidado y reparación de todos estos bienes, y el abono de los salarios y gastos necesarios para hacer frente a todas estas obligaciones. Los administradores no podían, sin embargo, percibir o entregar personal o directamente dinero alguno. Para ello contaban con la colaboración de un receptor o clavario. Durante los años inmediatamente posteriores a la expulsión de los moriscos hubo 3 clavarios: Sebastián Pérez -designado el 26 de febrero de 1610 y fallecido el 20 de julio del mismo año ${ }^{48}$ - Joaquín Larralde y Bastán -nombrado en sustitución de Pérez a finales del julio de 1610 - y Joaquín Ayerve -que ejerció la clavería durante los ejercicios 1615 a $1616^{49}$. Además de los clavarios, los administradores pudieron designar a dos procuradores, tarea de la que, por lo general, se ocuparon los notarios Simón Gorris y José Taix, aunque también intervino ocasionalmente el notario Silvestre de Urbina.

43. Conocemos estos extremos gracias al testimonio prestado el 6 de noviembre de 1613 por el administrador Alonso de Guevara. Vallterra desapareció muy pronto del escenario segorbino -a comienzos de 1610 poco más o menos. Sisternes, sin embargo, continuó ocupándose de todo los referente a la administración del expolio hasta 1617 por lo menos. ARV: Maestre Racional, exp. 10.117, fol. $17 \mathrm{r}$.

44. ARV: Maestre Racional, exp. 10.122.

45. Guevara poseía 5 censales por valor de 28.200 sueldos contra diferentes censatarios moriscos: Pedro Alabori, Jerónimo Edrís, Jerónimo Meddi, Gaspar Morsí, alias Patarni, Pedro Palomo, Luis Roget, alias Purri (de Geldo) y Catalina Torlit.

46. Guevara era tutor y curador de los hijos de Juan Noguera. ARV: Real Audiencia. Procesos. Parte Primera. Letra A, exp. 916.

47. ARV: Real Audiencia. Procesos. Parte Primera. Letra A, exp. 985. Se abordan en este proceso las consecuencias económicas de la frustración de las expectativas puestas por Guevara en el avituallamiento de las carnes del Arrabal como consecuencia de la expulsión de los moriscos.

48. ARV: Maestre Racional, exp. 10.117, fols. 19 r-19 v.

49. ARV: Maestre Racional, exps. 10.120 a 10.122. 
Las protestas y reclamaciones que podemos cosechar leyendo detenidamente los libros del expolio segorbino demuestran que la fórmula elegida no fue la más oportuna, ya que propició no pocos desmanes y fraudes, por otra parte previsibles dada la confusión de intereses privados y públicos dentro de la que actuaron los administradores del expolio. Sin embargo, enfrentada a una situación excepcional, la Corona tuvo que echar mano de fórmulas que -si no óptimas- sí parecían al menos las mejores de entre todas las posibles. Aun así, es necesario subrayar que los administradores se mostraron negligentes en toda una serie de cuestiones que finalmente provocarían la destitución de Guevara y la concentración de poderes en manos de Bosch: ${ }^{50}$ nunca acabaron de controlar suficientemente que las propiedades rústicas de los moriscos fueran atendidas y cultivadas a costum de bons llauradors, no comprobaron puntualmente la residencia y asentamiento definitivo de los nuevos colonos, desatendieron buena parte de las casas del Arrabal de modo que cerca de 50 de ellas comenzaron a amenazar ruina muy pocos años después de la expulsión ${ }^{51}$, se mostraron dispuestos a atender reclamaciones acerca del pago de la deuda censal de los moriscos no suficientemente justificadas -fraudulentas incluso- dejaron frutos sin cosechar, no vigilaron adecuadamente las operaciones de compraventa del dominio enfitéutico, ni cobraron los luismos que debieran haber sido reclamados, etc. ${ }^{52}$.

Durante los meses que siguieron a la expulsión de los moriscos, los administradores y clavarios trataron de cosechar todo el grano y el fruto que había quedado en los campos de los moriscos ${ }^{53} \mathrm{y}-\mathrm{al}$ mismo tiempo- de arrendar todas las propiedades rústicas y urbanas de los expulsos con el fin de hacer frente a las obligaciones que tenían contraídas tanto la Aljama cuanto los miembros particulares de la comunidad morisca de Segorbe. A decir verdad, durante los meses que siguieron al extrañamiento -es decir, durante la clavería de Sebastián Pérez- los administradores se vieron obligados a ceder una gran parte de las tierras moriscas en régimen de aparcería y únicamente consiguieron arrendar 2 plantaciones de moreras y de nogales, 2 huertos, 6 alfalfares

50. Esta circunstancia debió producirse a mediados del año 1615. Véase ARV: Maestre Racional, exp, 10.123, fol. $13 \mathrm{r}$.

51. Hasta tal punto de deterioro se llegó en no pocos casos que, finalmente, hubo que ceder bastantes casas del Arrabal de manera gratuita con la condición de que sus nuevos ocupantes atendieran a su reparación y evitasen su ruina. Ibídem, fol. $14 \mathrm{r}$.

52. No siempre descuidaron los administradores sus obligaciones. Ahora bien, cuando se aplicaron a la defensa de los intereses del Real Patrimonio, nunca dejaron los administradores de hacer valer -al mismo tiempo- los suyos propios. Nos referimos al momento (3-VIII-1611) en que Bosch y Guevara solicitaron a la Real Audiencia que obligase el consell segorbino a cumplir el acuerdo adoptado por el consejo municipal el 6 de marzo de 1597 por el que se comprometían a arrendar la dehesa o bovalar de Amara, Rascaña y Artel por solas 10 libras con el fin de favorecer la puja por el avituallamiento de las carnes del Arrabal, circunstancia que - como sabemos- tocaba muy de cerca a Alonso de Guevera. ARV: Real Audiencia. Procesos, Parte Primera. Letra A, exp. 923.

53. Por esta vía se cosecharon 211 cahíces y 21 barchillas de panizo, 4 cahíces de sorgo blanco y los nabos que habían quedado en la heredad de Jorollo de Geldo, cuyo valor conjunto fue estimado en 8.330 sueldos y 1 dinero. 
y 19 casas $^{54}$. Además de los desembolsos derivados del pago de intereses de censales garantizados con las propiedades de los moriscos expulsos a los que los administradores tuvieron que hacer frente, hubo que pagar a los agrimensores y veedores rurales de los que antes hemos hablado ${ }^{55}$ y arrendar un granero al canónigo Martín Juan Moreno para guardar el grano cosechado ${ }^{56}$. Durante el ejercicio siguiente -1-XI-1610 a 1-XI1611- la situación mejoró ostensiblemente. Una gran parte de las antiguas propiedades moriscas pudo ser arrendada a un precio que todavía cabría considerar no excesivamente lastrado por el descenso de la demanda. Si bien es verdad que a lo largo de estos doce meses comenzaron a protocolizarse los primeros establecimientos enfitéuticos con nuevos colonos cristiano-viejos, no es menos cierto que éstos no se hicieron efectivos hasta el ejercicio siguiente, de modo que la documentación que conservamos del expolio del Ducado de Segorbe para esta etapa puede ser considerada un reflejo representativo de la realidad socio-económica de los moriscos segorbinos antes de su expulsión. Esta será la principal baza documental de nuestro trabajo. Analizaremos su contenido a lo largo de las páginas que siguen.

\section{LOS BIENES DE LOS MORISCOS Y SU DESTINO: LA PROPIEDAD URBANA}

De la confección -y, por tanto, de la existencia- de uno o varios inventarios de las propiedades rústicas, urbanas y tal vez muebles de los moriscos segorbinos únicamente poseemos información indirecta ${ }^{57}$. Se alude a ellos en varias anotaciones del cuadernillo titulado Dubtes y memòries resultants de la certificatòria dels arrendaments de les terres dels moros expulsos de la ciudad de Sogorb del any MD. Cxi, por medio de las cuales los coadjutores del Maestre Racional expresaron su perplejidad y sus quejas acerca de lo negligentemente que habían sido presentadas para su inspección las cuentas del expolio del Ducado de Segorbe ${ }^{58}$. Los coadjutores tal vez poseyeran copia de estos documentos. En caso contrario les habría resultado extraordinariamente difícil llevar a cabo el seguimiento de las propiedades moriscas, es decir, el control de los ingresos derivados de su arrendamiento temporal, del valor de los frutos pertenecientes al real secuestro y de los establecimientos acordados con los nuevos repobladores y enfiteutas cristianos. En teoría, tales inventarios no sólo debieran haber recogido pormenorizadamente las propiedades requisadas por la Corona tras la expulsión, sino que

54. ARV: Maestre Racional, exp. 10.117,fols. 23 v-25 v.

55. Para retribuir el trabajo de estos veedores, los administradores Bosch y Guevara tuvieron que solicitar permiso para ello el 31 de marzo de 1610 al oidor de la Real Audiencia Marco Antonio Sisternes. Los administradores y el clavario recibieron permiso para gastar hasta 50 libras del expolio en estos menesteres a finales de abril del mismo año. ARV: Real Audiencia. Procesos. Parte Primera. Letra A, exp. 887.

56. ARV: Maestre Racional, exp. 10.117, fol. 26 r.

57. Los coadjutores del Maestre Racional indican en diversas ocasiones que los responsables del expolio han debido hacer - pues tenían obligación de ello- varios inventarios -tierras y casas, al menos. ARV:

Maestre Racional, exp. 10.117, fols. 15 r-16 r.

58. ARV: Maestre Racional. Exp. 10.119, cuaderno de duptes, $2^{\mathrm{a}}$ mano, fols. $3 \mathrm{r}-14 \mathrm{v}$. 
-además- debieran haber permitido confeccionar las plantillas para la presentación anual de las cuentas del expolio.

Nada podemos decir acerca del primer extremo, ya que, entre los papeles de la sección Maestre Racional del Archivo del Reino de Valencia no hemos conseguido localizar ninguna copia de los mismos. Sobre el segundo, podemos afirmar taxativamente que estos inventarios jamás fueron utilizados por los clavarios o receptores del expolio ni a la hora de confeccionar sus propios libros contables, ni en el momento de elevar el balance oficial al tribunal de cuentas del Real Patrimonio. Más aún, los clavarios del expolio jamás siguieron un mismo e idéntico patrón para la redacción de sus propios cuadernos, de modo que, aunque poseemos media decena de ellos, la comparación entre los mismos resulta extraordinariamente compleja. Varios aspectos dificultan el contraste entre estas fuentes. La falta de rigor en la identificación de los bienes dejados atrás por los moriscos -especialmente si se trataba de predios y propiedades agrarias-solía ser muy notable. En numerosas ocasiones no consta el nombre del antiguo propietario morisco y, a veces, ni siquiera aparece el apellido. En su lugar, el escribano anotaba el apodo o alias, impidiéndonos de este modo establecer con exactitud su identidad $^{59}$. Otro tanto cabría decir de la extensión, de las características de la parcela e, incluso, de su ubicación en una u otra partida del agro segorbino, datos estos que no siempre son reflejados de la misma manera, añadiendo una complejidad suplementaria al análisis del documento. El hecho de que en estos cuadernos sólo se anoten las propiedades arrendadas también dificulta el seguimiento de las mismas, ya que estas sólo constan si efectivamente han sido arrendadas, y -por tanto- no aparecerán documentadas si no se arriendan o se hubieran establecido previamente mediante contrato entitéutico. Un último aspecto perjudica la correcta interpretación de la fuente. Puesto que los arrendatarios cristiano-viejos solían alquilar lotes de tierras que incluían varias parcelas moriscas y no todos los años arrendaban los mismos lotes necesariamente, la identificación de las antiguas propiedades moriscas requiere dosis extraordinarias de paciencia y, en ocasiones, resulta completamente imposible ${ }^{60}$.

La valoración de la propiedad morisca que estamos en condiciones de realizar debe descansar, no obstante, sobre este tipo de fuente cuyos condicionamientos y pro-

59. Dejando de lado el hecho de que no pocos apodos - como si de otro bien se tratase- debieron pasar de abuelos a padres y a hijos sin solución de continuidad -circunstancia que el historiador no debiera pasar por alto al tratar de identificar las diferentes propiedades- hubo apodos idénticos que -no obstantepertenecieron a diferentes personas, como el Cojo, alias que solía acompañar a varios miembros de la familia Izquierdo - quién sabe si descendientes de un antepasado común-el Tuerto, apodo de un morisco apellidado Palomo y de otro apellidado Tunici -o Tunicí- o el Ciego, apodo de un tal Redondo y, asimismo, de un tal Taher.

60. Los coadjutores del Maestre Racional sospechaban que la permanente modificación de criterios, la dejadez y la incuria mostrada por los clavarios y los escribanos del expolio en la confección de los cuadernos contables pretendía camuflar todo tipo de irregularidades y -probablemente también- no pocos fraudes. A decir verdad, tras haber analizado con atención estos cuadernos y haber determinado que los máximos responsables de la administración del expolio estaban asimismo involucrados en la explotación económica del mismo, mucho nos tememos que los oficiales del Real Patrimonio estuviesen cargados de razón. 
blemas de interpretación acabamos de comentar de manera sumaria. A las dificultades apuntadas ya, se añade ahora la ineludible necesidad de escoger uno de los expedientes contables conservados, puesto que la comparación entre todos ellos estaba fuera de nuestro alcance, dada la enorme cantidad de tiempo que hubiera sido necesario invertir en un procedimiento tan agotador y minucioso como este. Así pues, asumiendo el triple riesgo que implica - por un lado- escoger un expediente entre varios, establecer -por otro- un fichero exhaustivo de propiedades identificables y -por último- efectuar una proyección o reconstrucción de los datos no plasmados en el documento con el fin de poder alcanzar algún resultado provechoso, hemos optado por estudiar con detenimiento el cuaderno de arrendamientos correspondiente al año 1611, titulado Còpia de la çertificatòria de totes les regalies del any mil sis-cents y once. Arrendament per un any, contador del dia de Tots Sants MD. Cx a Tots Sants MD. C xi ${ }^{61}$. Este documento, confeccionado bajo la conjunta responsabilidad de Mateo Bosch y Alonso de Guevara -administradores del expolio- Joaquín de Larralde y Bastán -clavario- y José Taix -notario- es notablemente más completo que el cuaderno correspondiente al período 1-XI-1609 a 1-XI-1610 62 , y, al mismo tiempo, recoge información sobre algunas propiedades que ya no volveremos a ver documentadas más, ya que -al parecer- los primeros establecimientos enfitéuticos se concertaron precisamente a lo largo del año $1611^{63}$.

En efecto, un asiento y una duda de los coadjutores de Maestre Racional correspondientes al ejercicio contable 1610-1611 demuestra que el entonces abogado fiscal del Consejo de Aragón, Dr. Salvador Fontanet ${ }^{64}$, estuvo en la ciudad de Segorbe durante 13 días consecutivos ocupándose de concertar y protocolizar los primeros establecimientos enfitéuticos del Arrabal de Segorbe con los nuevos repobladores ${ }^{65}$. El fiscal catalán llegó a Segorbe en un carruaje tirado por cabalgaduras y durante su

61. Este cuaderno de 93 folios consta en el exp. 10.118 de la sección Maestre Racional del ARV. Aunque este documento ha sido utilizado por otros historiadores y presuntos colegas que confunden el deber de enseñar y de corregir con una cruzada personal, las numerosas deficiencias metodológicas, las incontables inexactitudes cuantitativas y el carácter incompleto de su aproximación al tema, aconsejan no hacer uso de sus resultados, ni tan sólo aludir a él, ahorrando así a los lectores bienintencionados una innecesaria pérdida de tiempo.

62. ARV: Maestre Racional, exp. 10.117.

63. Es cierto, sin embargo, que algunos otros expedientes posteriores - tal y como hemos podido comprobarcontienen información sobre propiedades no arrendadas en 1610, ni en 1611, ni establecidas a censo durante los primeros años del expolio, aunque - a decir verdad- su importancia parece pequeña y su existencia apenas condiciona los resultados obtenidos a través del estudio del expediente 10.118 .

64. Arrieta Alberdi, Jon: El Consejo Supremo de la Corona de Aragón (1494-1707), Zaragoza, 1995, pág. 613.

65. Los coadjutores del Maestre Racional pusieron en duda la legitimidad de un pago de 2.969 sueldos - nada menos que 148 libras- a mosén Noguera por haber alojado y dado de comer en su casa al Dr. Salvador Fontanet durante casi dos semanas, ya que Fontanet disponía de dietas con qué satisfacer este tipo de gastos. Ahora bien, como los intereses del Fiscal del Consejo y del beneficiado coincidían en esta ocasión, y el procurador del Duque de Cardona, D. Antonio Manuel de Castro, no puso objeción alguna, los coadjutores tuvieron que «hacer la vista gorda» y se vieron obligados a renunciar a la pesquisa que tenían previsto realizar. ARV: Maestre Racional, exp. 10.119, cuaderno de duptes, $2^{\mathrm{a}}$ mano, fols. $8 \mathrm{v}-9 \mathrm{r}$. 
estancia estuvo hospedado en el domicilio del beneficiado Damián Noguera, uno de los presbíteros segorbinos que más se involucraron en el apoyo logístico de la administración del expolio segorbino ${ }^{66}$. Puesto que la visita del Dr. Fontanet se produjo en 1611 , cuando ya se habían concertado y anotado los arrendamiento de las antiguas propiedades moriscas, parece oportuno servirse del cuaderno correspondiente al ejercicio 1610-1611 porque, además de su elevado nivel de información, los establecimientos firmados por el Fiscal -se realizasen o no con sus arrendatarios-deben constar en este documento -al menos, una mayoría de los mismos.

Otra destacada característica de este cuaderno aconseja no servirse de otro para obtener una foto fija -aunque sea forzoso reconocer que un tanto desenfocada- de la propiedad morisca en los días previos a la expulsión. Nos referimos al precio acordado para los arrendamientos, que todavía en 1611 debía continuar -en gran medida- reflejando el valor de los bienes, dado que, a partir de 1612, percibimos una clara disminución del precio de los arrendamientos, en consonancia con el debilitamiento de la demanda. Este rasgo otorga al expediente 10.118 una importancia singular, ya que ningún otro permite atisbar el valor de los inmuebles abandonados por los moriscos con ciertas garantías de verosimilitud, ya que los anteriores carecen de información suficiente y los posteriores ya acusan la devaluación de las antiguas posesiones moriscas.

El cuaderno de arrendamientos incluido en el expediente 10.118 se halla dividido en un total de 33 grandes apartados que corresponden -esencialmente- a las diferentes partidas rurales segorbinas y a las antiguas viviendas y dependencias moriscas del Arrabal de la ciudad de Segorbe. La presentación de los diferentes alquileres acordados para el año 1611 no parece responder a criterios abstractos, sino, más bien, a otros muy concretos de carácter geográfico o topográfico ${ }^{67}$. Con los datos de este cuaderno y siguiendo sus propias indicaciones, sería posible individualizar 3 grandes grupos de arrendamientos: urbanos y rústicos - por una parte- divididos éstos últimos -a su vezen alquileres correspondientes a parcelas de regadío y de secano. Aunque no es posible afirmar taxativamente que en estas fechas no se hubieran realizado ya unos pocos establecimientos enfitéuticos a vecinos de Segorbe, habitantes de las poblaciones cercanas o repobladores procedentes de los más diversos lugares, todo parece indicar que los bienes arrendados en 1611 representaban muy probablemente un porcentaje muy significativo de las primitivas propiedades moriscas. Dentro de este bloque, el estatuto originario de los bienes dados en alquiler debió ser diverso. De hecho, junto con las

66. Es posible que Noguera se implicase activamente en este asunto, entre otros muchos motivos, para asegurarse la percepción de las rentas de su beneficio eclesiástico - el de Santa Ana de la Seo de Segorbe- que procedían de un censal cargado contra la Aljama segorbina. Damián Noguera fue, en efecto, uno de los pocos eclesiásticos que apenas notaron la expulsión de los moriscos, ya que su beneficio fue asumido desde el primer momento por la administración del expolio y satisfecho religiosamente desde 1610 en adelante. ARV: Maestre Racional, exps. 10.117, fol. 9 r, 10.118, fol. 20 r y 10.119, fol. 20 v.

67. En efecto, algunas partidas aparecen individualizadamente, mientras que otras aparecen formando parte de un grupo, sin que ello parezca obedecer al principio de establecer grupos más o menos homogéneos en extensión o valor. 
propiedades comunales pertenecientes a la Aljama o con la Obra Pía de la Parroquia de San Pedro ${ }^{68}$, podemos encontrar bienes francos, propiedades hipotecadas y dominios enfitéuticos pertenecientes al Ducado, así como a algunos otros propietarios directos, como la Cartuja de Valdecristo o el caballero Francisco Jerónimo Ramo y Medina, patrono del beneficio de San Valero de la catedral de Segorbe ${ }^{69}$.

Por lo que respecta a las propiedades urbanas, un documento del año 1615 permite determinar que el Arrabal segorbino estaba integrado por un total de 270 inmuebles, de los cuales 50 aproximadamente resultaban inhabitables, bien por sus funcionalidad, bien por su grado de deterioro, bien por carecer de las condiciones mínimas necesarias. Ninguna de estas 50 dependencias había conseguido ser arrendada desde el año 1610 $\mathrm{y}$-de hecho- en 1615 todas amenazaban ruina. Hemos podido tener conocimiento de estas circunstancias gracias las instrucciones dadas en Liria por el comisario real Adrián Bayarte al baile de Segorbe y síndico del expolio Mateo Bosch el día 26 de octubre de $1615^{70}$. Si restamos estos 50 inmuebles de los 270 que componían el Arrabal, alcanzamos la cifra de 220 viviendas en disposición de ser arrendadas. Pero los moriscos no sólo habitaban en el Arrabal. Fuera, en algunas otras barriadas extramuros de la ciudad -principalmente en el área conocida desde antiguo como la Almunia del Señor, alrededor del palacio ducal de la Plaza del Agua Limpia- los moriscos segorbinos habían poseído otras 80 casas aproximadamente ${ }^{71}$. Apenas poseemos información acerca de este grupo de 80 inmuebles, de modo que supondremos que todos ellos se hallaban en condiciones de ser arrendados ${ }^{72}$.

Aunque no hemos considerado oportuno servirnos de otro tipo de información que aquella reflejada en el expediente 10.118, no podemos pasar por alto que el expediente anterior 10.117 -donde constan los arrendamientos del año 1610- contiene información muy interesante para el estudio de la propiedad urbana morisca. A diferencia de lo sucedido con las tierras y los cultivos, un porcentaje muy significativo de las viviendas moriscas pudieron ser arrendadas el año 1610. Concretamente, los responsables del expolio entregaron en régimen de alquiler un total de 159 casas, 1 carreronet, 2 tien-

68. La parroquia de San Pedro fue erigida como parroquia exclusiva para moriscos - es decir, como parroquia específicamente dedicada a la evangelización de los «impermeables» moriscos- por el obispo Feliciano Figueroa el 18 de junio de 1599, a tenor de la orden del papa Clemente VIII y del mandato real de 16 de febrero de 1596. Llorens RagA, Peregrín: Los moriscos y la parroquia de San Pedro de la ciudad de Segorbe, Segorbe (Biblioteca de Estudios de Segorbe y su comarca, $\left.n^{\circ} 7\right), 1958$.

69. Entre las propiedades administradas por el expolio del Ducado de Segorbe todavía en 1615, Valdecristo era señor eminente de 25 heredades y Francisco J. Ramo y Medina, en su calidad de patrono del beneficio de San Valero, de un total de 56 casas, 3 corrales y 9 predios y huertos. ARV: Maestre Racional, exp. 10.122, ítems. $\mathrm{n}^{\mathrm{os}} .187$ y 188.

70. ARV: Maestre Racional, exp. $10.123 \mathrm{~m}$ fol. $13 \mathrm{v}$.

71. La cifra es puramente arbitraria, pues ha sido obtenida restando a 350 fuegos del listado del Marqués de Caracena las 270 viviendas del Arrabal.

72. Podríamos haber aplicado un porcentaje semejante -igual, disminuido o proporcional-al existente en el Arrabal para el cálculo de los edificios inapropiados, inservibles o en ruinas, pero hemos preferido no complicar en exceso el estudio de esta cuestión. 
das, 1 tinte, 2 corrales y 19 huertos. Es decir, cerca de un 45\% de las propiedades abandonadas por los moriscos a finales del año 1609 fueron alquiladas por cristiano-viejos segorbinos en el año 1610. Las referencias bastante precisas acerca de la ubicación de los inmuebles nos ha permitido determinar que, aunque la mayor parte de ellos se hallaba dentro de los límites del Arrabal, no dejaron de alquilarse algunas otras casas en el área de la Almunia, en torno al llamado carreronet de los naranjos. Las anotaciones realizadas por el escribano en el expediente 10.117 permitirían una reconstrucción aproximada de los grandes ejes urbanísticos del Arrabal segorbino, puesto que, junto al nombre del antiguo propietario moriscos, figuran -en ocasiones- el de la calle y el de las viviendas limítrofes ${ }^{73}$.

El año siguiente 1611 el número de arrendamientos creció. Un total de 183 cristiano-viejos segorbinos alquiló un conjunto de inmuebles cifrado en 185 unidades, entre las cuales figuraban 9 antiguas tiendas o botigues, una jabonería, un tinte, un corral y 3 escaletas, es decir, viviendas estrechas cuyas diversas partes comunicaban entre sí por medio de una escalera. Cinco de estos edificios disponían de un pequeño patio, jardín o huerto, y otros 2 poseían un corral más o menos amplio. Podría afirmarse, pues, que en 1611 se arrendó aproximadamente el 62\% de la propiedad urbana morisca, integrada tal vez por unos 350 inmuebles $^{74}$ de los que hemos suprimido 50 por los motivos señalados anteriormente. El alquiler de las 185 viviendas reportó a la administración del expolio un total de 491 libras, 10 sueldos y 5 dineros. El precio medio del arrendamiento anual de estas 185 casas se aproximaba, pues, a las 2 libras y los 8 sueldos anuales en el año 1611. Desde luego, no faltaban viviendas algo más valiosas ${ }^{75}$, pero ninguna superó las 15 libras de alquiler anual pagadas por el Dr. Miguel Porcar, deán de la catedral del Segorbe, por el caserón que había pertenecido al morisco Juan Taher $^{76}$. Si suponemos que el precio medio alcanzado por los alquileres anuales podía representar entonces el 5\% ${ }^{77}$ del valor del inmueble, podría plantearse entonces que

73. Las referencias urbanísticas son, en efecto, muchas: la acequia, la calle del albellón -junto con la rinconada del albellón- calle de los Bellvís, calle Castelnovo - que se prolongaba por el camino de Castelnovocalle de en medio -y la rinconada del mismo nombre- calle de las eras largas, calle de los Izquierdos, calle del horno, calle de Mormani, calle de la rinconada, camino de Valencia, la cantarería, el carreronet de los naranjos, el cementerio de los judíos, la Concepción -y la bajada del mismo nombre- el chorro de Marrán, los cuatro cantones, el escorxador, la fuente cerca de la puerta del cementerio, el propio fosar o cementerio morisco, el mercado, la placeta de la morería, placeta del portal de la eras largas, los porches del mercado, el portalico al lado del mercado, el portalico quemado, el portal de Castelnovo, el portal del horno de abajo, el portal de Vicent Remón, la rinconada situada bajo del horno de arriba, la rinconada de Miquel Valenci, San Pedro y la bajada de San Pedro, la subida del alaverde -que daba comienzo en el mercado- el tinte $-\mathrm{y}$ su rinconada- los tiradores - junto con la fuente- etc.

74. PÉrez GarcíA, P.: Op. cit., pág. 375.

75. Un total de 11 casas superaron las 7' 5 libras de alquiler anual. Habían pertenecido a la Aljama, a Lorenzo Benazar hijo, a Joan Çafar, a los Chovis, a Juan Nader, Jerónimo Najar, a Francisco Patarni (casa y tienda), Gaspar Patarni (casa y huerto), a Jerónimo Razín, a Juan Razín (casa y tienda) y a Juan Taher.

76. ARV: Maestre Racional, exp. 10.118, fol. 47 r.

77. Como porcentaje de referencia hemos utilizado el interés estándar de un censal. 
el valor de estos 185 inmuebles se hallaba cercano en 1611 a las 10.000 libras -9.830 libras concretamente. Si ahora extrapolamos los promedios obtenidos al conjunto de los 300 inmuebles habitables del Arrabal y demás barriadas extramuros obtenemos una cifra cercana a las 15.940 libras. Y si, por último, concedemos un valor 10 veces inferior al de los inmuebles habitables a aquellos otros 50 que en 1615 amenazaban ruina, el valor conjunto de la propiedad urbana morisca de Segorbe podría hallarse cercano a las 16.200 libras valencianas.

\section{LOS BIENES DE LOS MORISCOS Y SU DESTINO: LA PROPIEDAD RURAL}

El estudio de la propiedad agraria de los moriscos segorbinos resulta bastante más complejo. A diferencia de la propiedad inmueble, no disponemos de referencias -siquiera aproximadas- acerca de la entidad global del dominio rural morisco y, en consecuencia, sólo nos cabe reflexionar sobre los datos del cuaderno de arrendamientos del año 1611. Como sabemos, las propiedades agrarias de los moriscos se repartían por buena parte del agro segorbino, aunque la mayor parte de las mismas -tanto en número, cuanto en extensión y valor- se concentraban en el regadío. Dentro del área irrigada, el cuaderno de arrendamientos de 1611 contempla un total de 24 subdivisiones muy diversas: partidas, grupos de partidas, caminos, huertos y alfalfares ${ }^{78}$. Dentro del secano, las subdivisiones contempladas por el expediente 10.118 son 8: también parcelas singulares, agrupaciones, viñas y algarrobales. Aunque en cuadro aparte ofrecemos los datos pormenorizados, por razones obvias nuestro análisis de ceñirá a la simple diferenciación entre secano y regadío.

Antiguas propiedades rurales moriscas arrendadas el año 1611

\begin{tabular}{|c|c|c|c|c|c|c|}
\hline & $\begin{array}{c}\mathrm{n}^{0} \text { parcelas } \\
\text { moriscas }\end{array}$ & $\begin{array}{c}n^{0} \text { lotes } \\
\text { cristianos }\end{array}$ & $\begin{array}{c}\text { extensión } \\
\text { global } \\
\text { original } \\
\text { (en Han.) }\end{array}$ & $\begin{array}{l}\text { extensión } \\
\text { reconstr. } \\
\text { (en Han.) }\end{array}$ & $\begin{array}{c}\text { valor } \\
\text { global } \\
\text { arrendam. }\end{array}$ & $\begin{array}{l}\text { parcelas } \\
\text { extensión } \\
\text { conocida / } \\
\text { parcelas } \\
\text { totales }\end{array}$ \\
\hline Regadío & $776+i ?$ & 558 & $1.87575+i ?$ & $2.094^{\prime} 25$ & 2.095 L. 7 s. 8 d. & $672 / 776$ \\
\hline Secano & $312+i ?$ & 208 & $22^{\prime} 5+i ?$ & $1.817+i ?$ & 451 L. 2 s. 8 d. & $22 / 312$ \\
\hline TOTAL & $1.088+i ?$ & 776 & $1.898^{\prime} 25+i ?$ & $3.911 ' 25+i ?$ & 2.546 L. 10 s. 4 d. & $694 / 1.088$ \\
\hline
\end{tabular}

Desde un punto de vista formal, el cuaderno de arrendamientos del año 1611 sólo permite documentar de una manera completa y exhaustiva la identidad del arrendatario cristiano-viejo, la de su fiador y la suma o la anualidad satisfecha. La información acerca de los restantes aspectos que de una manera u otra se recogen en el documento resulta siempre azarosa: a veces no consta el nombre del antiguo propietario morisco, o su identificación no resulta precisa, o no siempre es posible determinar la extensión de

78. Dentro de estas 24 subdivisiones figura el hinterland rural de la población de Navajas como si se tratase de una partida más de Segorbe, si bien los antiguos propietarios de sus parcelas parecen haber sido todos ellos vecinos de Navajas. 
la parcela o el dominio, ni el tipo de cultivo o de explotación aparece sistemáticamente reflejado. Para conseguir una imagen más acorde con la realidad que aquella que habríamos podido obtener a través de los datos desnudos del expediente 10.118, ha habido que establecer una correlación media - específica para cada partida- entre extensión y precio de arrendamiento, con el fin de calcular la superficie aproximada de la tierra cuando este dato faltaba en la documentación. Aun así, no siempre ha sido posible efectuar una proyección, de modo que antes que especular sobre datos no contrastables, hemos preferido informar al lector de la existencia de un margen de incertidumbre muy difícil de precisar, del cual hemos dejado constancia mediante el signo $i ?^{79}$.

El primer rasgo destacable del cuaderno de 1611 en lo tocante al arrendamiento de la propiedad rural segorbina es -sin duda- la imprecisión general a la hora de reflejar la extensión de los predios. Esta característica, perceptible -aunque superable- en el caso del regadío, presenta un peso abrumador en el caso del secano, donde tan sólo tenemos documentada la extensión de 22 de las aproximadamente 312 parcelas que pertenecieron a los moriscos. Nuestro grado de información sobre la huerta de Segorbe es mucho mayor, aunque a decir verdad desconocemos la extensión exacta de 104 de las 776 antiguas propiedades moriscas. La falta de información condiciona -y mucho- cualquier intento de aproximación general al tema, ya que, según nuestras proyecciones y cálculos, el número total de hanegadas que podemos documentar con precisión podría representar sólo la mitad, aproximadamente, del conjunto documentable si el escribano hubiera anotado sistemáticamente la extensión precisa de todas las antiguas parcelas que pertenecieron a los moriscos ${ }^{80}$. En conjunto, desconocemos, pues, la extensión de un 36\%-394 parcelas- de las 1.088 propiedades agrarias moriscas arrendadas en 1611 . La información disponible acerca de las 694 parcelas restantes arroja un extensión total de algo más de 1.898 hanegadas, de las cuales el 99\% correspondería a regadío y el 1\% restante a secano. Las cifras reconstruidas proyectan, sin embargo, una imagen muy distinta, ya que estas antiguas 1.088 propiedades moriscas muy bien podrían haber sumado, en realidad, unas 3.900 hanegadas, el 53\% de las cuales (2.094 han.) podría haber correspondido a antiguas propiedades de huerta y el $47 \%$ restante (1.817 han.) a secano.

La extensión media de una propiedad agraria morisca antes de la expulsión podría haber rondado las 3'6 hanegadas. Esta cifra -obtenida al dividir las 3.911 hanegadas de nuestra proyección por las 1.088 parcelas moriscas- constituye un promedio mucho más exacto que el que hubiéramos obtenido dividiendo las 1.898 hanegadas docu-

79. Este margen de incertidumbre afecta esencialmente a la partida o zona conocida como el monte, dentro de la cual quedaron sin arrendar toda una serie de algarrobos que, no obstante, produjeron $204 @$ de algarrobas que se vendieron por 25'5 libras. ARV: Maestre Racional, exp. 10.118, fol. 75 r.

80. Aunque no disponemos de espacio suficiente para detallar pormenorizadamente nuestros cálculos, el criterio utilizado para la reconstrucción ha consistido siempre en la obtención de un precio medio -de arrendamiento anual- por hanegada para cada una de las partidas reflejadas en la documentación y en la división del arrendamiento concertado para la obtención del número de hanegadas no reflejado por el escribano. 
mentadas por las 694 parcelas sobre las que poseemos información precisa, ya que la falta de datos sobre las propiedades en el secano -donde estas poseían una extensión necesariamente mayor- compromete de una manera clara los resultados. Cuando los cristianos viejos segorbinos tuvieron que plantearse la eventualidad de arrendar estas propiedades, a la luz de lo reflejado en el cuaderno de arrendamientos de 1611, resulta evidente que no se conformaron con pujar por las antiguas propiedades moriscas como tales, sino que trataron de hacerse con dos o más -limítrofes entre sí- con el fin de conseguir predios más extensos, supuestamente más productivos o, al menos, más rentables. Si dividimos 3.911 hanegadas por los 776 lotes constituidos por los arrendatarios cristiano-viejos, obtenemos un promedio general de 5 hanegadas, cifra que representa una extensión casi 40\% superior a las 3'6 hanegadas de una propiedad media morisca antes de 1609. Lógicamente, la extensión media de las antiguas posesiones moriscas y la de los nuevos arrendamientos cristianos variará según se trate del regadío o del secano. En el secano, la propiedad media de los moriscos bien pudo alcanzar las 5'8 hanegadas -y 8'7 hanegadas cada uno de los lotes arrendados por cristiano-viejosmientras que en la huerta el promedio podría haberse reducido hasta las 2'7 hanegadas en el caso de los moriscos y las 3'7 hanegadas en el caso de los cristianos viejos ${ }^{81}$.

El precio alcanzado por el arrendamiento de las antiguas propiedades moriscas constituye -sin duda- uno de los aspectos cruciales del tema que nos ocupa, no ya como reflejo del impacto provocado por la expulsión de los moriscos sobre la economía local, sino también como indicador o índice del valor de la propiedad agraria de los moriscos expulsos. En este sentido -siempre y cuando la reconstrucción que proponemos haya sido correctamente proyectada- podría afirmarse que, en general, la hanegada en el regadío segorbino era arrendable en 1611 por una libra -20 sueldos- al año, mientras que esta misma hanegada en el secano sólo alcanzaba niveles cercanos a los 5 sueldos anuales, es decir, un valor 4 veces inferior al del regadío. En efecto, las poco más de 2.095 libras por las que se arrendaron las algo más de 2.094 hanegadas moriscas en la huerta de Segorbe arrojan este promedio de una libra, mientras que las 451 libras -9.020 sueldos- por las que se arrendaron las poco más de 1.817 hanegadas en el secano segorbino da como resultado los prácticamente 5 sueldos a los que acabamos de referirnos. Cabría señalar, por último, que el conjunto de la propiedades agrarias de los moriscos segorbinos alcanzaron un promedio de 13 sueldos por hanegada en las operaciones de arrendamiento suscritas por la administración del expolio y los particulares para el año 1611.

Si utilizamos los mismos criterios para la estimación del valor de la propiedad agraria que hemos aplicado al cálculo del valor de la propiedad urbana, es decir, si

81. Las diferencias de tamaño y explotación existentes entre las antiguas parcelas moriscas y las propiedades o lotes constituidos por los repobladores y colonos cristianos -así como el impacto que estas modificaciones pudieron tener en el avance de una agricultura más productiva y competitiva- han sido cuestiones puestas de relieve por Manuel Ardit en diversos trabajos. ARDIT LUCAS, Manuel: «Expulsió dels moriscos: creixement agrari al País Valencià», Afers. Fulls de Recerca i Pensament, Catarroja, 1987, nºs. 5-6, págs. 273-316. Más recientemente, «La historia rural de la España oriental durante la edad moderna: un estado de la cuestión», Studia Historia. Historia Moderna, Salamanca, 2007, n² 29, págs. 47-82. 
tomamos el precio alcanzado por el arrendamiento anual de las diferentes parcelas como un 5\% de la entidad patrimonial de los predios, podría afirmarse entonces que el valor de las antiguas propiedades moriscas en la huerta de Segorbe debió estar cerca de las 42.000 libras, mientras que el valor de las heredades en el secano podría haber rondado las 9.000 libras. En general, pues, nos hallaríamos ante un conjunto de posesiones agrarias cuyo valor global podría haber sido de unas 50 ó 51.000 libras. Puesto que desconocemos la proporción de tierras moriscas arrendadas en 1611 respecto del conjunto de los predios abandonados tras la expulsión, resulta enormemente comprometido pronunciarse acerca del valor global de la propiedad agraria morisca en 1609. No obstante, a modo de mera aproximación propondremos dos estimaciones posibles: una idéntica a la que hemos podido documentar en el caso de la propiedad urbana - es decir, del 62\%- y otra puramente arbitraria del $80 \%$. El valor de arrendamiento virtual que aplicaremos a la presunta proporción no documentada será el promedio general de 13 sueldos por hanegada que hemos obtenido. El número de hanegadas moriscas no arrendadas el año 1611 podría haber estado, por tanto, comprendido entre 979 [ $=4.890-3.911]$ y 2.389 [= $6.300-3.911]$, cifras que, multiplicadas por 13 sueldos, arrojarían un precio potencial de arrendamiento anual de entre 636 y 1.552 libras. Estas dos sumas, multiplicadas por 20 para obtener una estimación de su valor general en 1611, arrojarían una horquilla de entre 13.000 y 30.000 libras. Así pues, el valor global de las propiedades agrarias expoliadas a los moriscos segorbinos tras la expulsión podría haber estado comprendido entre un mínimo de 51.000 libras y un máximo -añadiendo otras 30.000 libras más- de 80.000 , aunque posiblemente la cifra más cercana a la realidad podría hallarse a medio camino entre las dos, es decir, en torno a unas 63 ó 64.000 libras.

Antiguas propiedades moriscas arrendadas en 1611

(detalle de las partidas del agro segorbino y de los epígrafes del cuaderno de arrendamientos de 1611)

\begin{tabular}{|c|c|c|c|c|c|c|c|}
\hline & $\begin{array}{c}\mathbf{n}^{0} \\
\text { parcelas } \\
\text { moriscas }\end{array}$ & $\begin{array}{c}\mathbf{n}^{0} \text { lotes } \\
\text { cristianos }\end{array}$ & $\begin{array}{c}\text { extensión } \\
\text { global } \\
\text { original } \\
\text { (en Han.) }\end{array}$ & $\begin{array}{l}\text { extensión } \\
\text { reconstr. } \\
\text { (en Han.) }\end{array}$ & $\begin{array}{c}\text { valor global } \\
\text { arrendam. }\end{array}$ & $\begin{array}{c}\text { estimación } \\
\text { del valor de la } \\
\text { tierra }\end{array}$ & $\begin{array}{c}\text { parcelas } \\
\text { extensión } \\
\text { conocida /parcelas } \\
\text { totales }\end{array}$ \\
\hline \multicolumn{8}{|l|}{ REGADÍO } \\
\hline Agustina & 18 & 12 & $47^{\prime} 00$ & $47^{\prime} 00$ & 34 L. 10 s. 0 d. & $690 \mathrm{~L}$. & $18 / 18$ \\
\hline Albacet & 28 & 24 & 63’00 & $71^{\prime} 00$ & 98 L. 13 s. 6 d. & $1.972 \mathrm{~L}$. & $23 / 28$ \\
\hline Albalat & 66 & 51 & $169 ’ 50$ & $200 ’ 00$ & 247 L. 14 s. 10 d. & $4.954 \mathrm{~L}$. & $62 / 66$ \\
\hline Alfalfares & 34 & 29 & $65^{\prime} 00$ & 73 '50 & 81 L. 16 s. 6 d. & $1.635 \mathrm{~L}$. & $30 / 34$ \\
\hline Almagrán & 72 & 53 & $145 ' 50$ & $145^{\prime} 50$ & 118 L. 14 s. 8 d. & $2.374 \mathrm{~L}$. & $72 / 72$ \\
\hline Artel & 16 & 8 & $6 ' 00$ & $48^{\prime} 00$ & 13 L. 5 s. 1 d. & $265 \mathrm{~L}$. & $1 / 16$ \\
\hline $\begin{array}{l}\text { Camino } \\
\text { Castelnovo }\end{array}$ & 5 & 5 & $11 ' 50$ & $11 ' 50$ & 27 L. 0 s. 8 d. & $540 \mathrm{~L}$. & $5 / 5$ \\
\hline Camino de Geldo & 6 & 5 & $11^{\prime} 00$ & $14^{\prime} 00$ & 6 L. 0 s. 6 d. & $120 \mathrm{~L}$. & $5 / 6$ \\
\hline $\begin{array}{l}\text { Camino de } \\
\text { Valencia }\end{array}$ & 3 & 3 & 6’00 & $9 ' 50$ & 9 L. 12 s. 2 d. & $180 \mathrm{~L}$. & $1 / 3$ \\
\hline Campo & 20 & 13 & $60 ’ 00$ & $70^{\prime} 00$ & 24 L. 3 s. 7 d. & $480 \mathrm{~L}$. & $16 / 20$ \\
\hline
\end{tabular}


PABlo PÉReZ García y BlanCa EsPuig CORELl

\begin{tabular}{|c|c|c|c|c|c|c|c|}
\hline & $\begin{array}{c}\mathbf{n}^{0} \\
\text { parcelas } \\
\text { moriscas }\end{array}$ & $\begin{array}{c}\mathrm{n}^{0} \text { lotes } \\
\text { cristianos }\end{array}$ & $\begin{array}{l}\text { extensión } \\
\text { global } \\
\text { original } \\
\text { (en Han.) }\end{array}$ & $\begin{array}{l}\text { extensión } \\
\text { reconstr. } \\
\text { (en Han.) }\end{array}$ & $\begin{array}{l}\text { valor global } \\
\text { arrendam. }\end{array}$ & $\begin{array}{c}\text { estimación } \\
\text { del valor de la } \\
\text { tierra }\end{array}$ & $\begin{array}{c}\text { parcelas } \\
\text { extensión } \\
\text { conocida /parcelas } \\
\text { totales }\end{array}$ \\
\hline Cascajo & 4 & 4 & $10^{\prime} 00$ & $10^{\prime} 00$ & 6 L. 11 s. 0 d. & $120 \mathrm{~L}$. & $4 / 4$ \\
\hline Castejón & 74 & 57 & $231^{\prime} 00$ & $264^{\prime} 00$ & 278 L. 3 s. 4 d. & $5.560 \mathrm{~L}$. & $67 / 74$ \\
\hline el Censal & 124 & 80 & $334^{\prime} 00$ & $346^{\prime} 00$ & 273 L. 11 s. 0 d. & $5.540 \mathrm{~L}$. & $121 / 124$ \\
\hline los Corrales & ¿? & 1 & ¿? & $32^{\prime} 00$ & 34 L. 11 s. 11 d. & $690 \mathrm{~L}$. & $i ? / i ?$ \\
\hline $\begin{array}{l}\text { Cuencas y } \\
\text { Albusquet }\end{array}$ & 13 & 12 & $32 ’ 50$ & $41 ' 50$ & 38 L. 15 s. 2 d. & $775 \mathrm{~L}$. & $11 / 13$ \\
\hline $\begin{array}{l}\text { la Franquesa } \\
\text { (Camino de } \\
\text { Capuchinos) }\end{array}$ & 5 & 2 & $20 ’ 00$ & $20 ’ 00$ & 34 L. 0 s. 0 d. & $680 \mathrm{~L}$. & $5 / 5$ \\
\hline Gallega & 41 & 29 & $87 ’ 25$ & $90 ’ 25$ & 119 L. 3 s. 5 d. & $2.380 \mathrm{~L}$ & $39 / 41$ \\
\hline Hortelano & 31 & 20 & $105^{\prime} 00$ & $105^{\prime} 00$ & 119 L. 16 s. 0 d. & $2.390 \mathrm{~L}$. & $31 / 31$ \\
\hline $\begin{array}{l}\text { Huertos y Eras en } \\
\text { Segorbe }\end{array}$ & 31 & 31 & ¿? & $20 ’ 00$ & 123 L. 7 s. 8 d. & $2.467 \mathrm{~L}$ & $0 / 31$ \\
\hline Marroyo & 2 & 1 & $1 ' 50$ & $1 ' 50$ & 15 s. 0 d. & $15 \mathrm{~L}$. & $2 / 2$ \\
\hline Navajas & 126 & 80 & $333 ' 50$ & 333 '5 & 175 L. 10 s. 6 d. & $3.510 \mathrm{~L}$. & $105 / 126$ \\
\hline Sopeña & 1 & 1 & $7 ’ 00$ & $7 ’ 00$ & 3 L. 5 s. 0 d. & $65 \mathrm{~L}$. & $1 / 1$ \\
\hline Torrejón & 7 & 4 & $14^{\prime} 00$ & $18^{\prime} 00$ & 82 L. 6 s. 0 d. & $1.648 \mathrm{~L}$. & $4 / 7$ \\
\hline Utrillas & 48 & 33 & $115^{\prime} 50$ & $115^{\prime} 50$ & 144 L. 0 s. 2 d. & $2.880 \mathrm{~L}$ & $48 / 48$ \\
\hline Total Regadío & $\begin{array}{c}776+ \\
i ?\end{array}$ & 558 & $\begin{array}{c}1.875,75 \\
+i ?\end{array}$ & $2.094^{\prime} 25$ & 2.095 L. 7 s. 8 d. & $41.900 \mathrm{~L}$. & $672 / 776$ \\
\hline \multicolumn{8}{|l|}{ SECANO } \\
\hline $\begin{array}{l}\text { Algarrobales } \\
\text { del Monte }^{1}\end{array}$ & ¿? & 0 & ¿? & ¿? & 25 L. $10 \mathrm{~s}$. & $510 \mathrm{~L}$. & ¿? \\
\hline $\begin{array}{l}\text { Amara, Olivar, } \\
\text { Rascaña y Haurín }\end{array}$ & 129 & 99 & ¿? & 485 & 103 L. 14 s. 4 d. & $2.072 \mathrm{~L}$. & $17 / 129$ \\
\hline Cima de Bonet & 8 & 4 & ¿? & 19 & 4 L. 18 s. 11 d. & $100 \mathrm{~L}$. & $0 / 8$ \\
\hline $\begin{array}{l}\text { Lagunas y } \\
\text { Majanos }\end{array}$ & 4 & 3 & ¿? & 30 & 3 L. 15 s. 11 d. & $75 \mathrm{~L}$. & $0 / 4$ \\
\hline $\begin{array}{l}\text { La Loma (junto } \\
\text { a la Rambla) }\end{array}$ & 8 & 7 & ¿? & 83 & 10 L. 0 s. 2 d. & $200 \mathrm{~L}$. & $1 / 8$ \\
\hline Reboll y otras ${ }^{2}$ & 70 & 44 & ¿? & 400 & 240 L. 18 s. 3 d. & $4.818 \mathrm{~L}$. & $0 / 250$ \\
\hline $\begin{array}{l}\text { Rodana y las dos } \\
\text { Cabreras }\end{array}$ & 30 & 19 & ¿? & 200 & 24 L. 3 s. 0 d. & $482 \mathrm{~L}$. & $0 / 30$ \\
\hline VIÑNAS $^{3}$ & 63 & 32 & $22^{\prime} 50$ & 600 & 38 L. 2 s. 1 d. & $762 \mathrm{~L}$. & $4 / 63$ \\
\hline Total Secano & $\begin{array}{c}312+ \\
i ?\end{array}$ & 208 & $22^{\prime} 5+i ?$ & $\begin{array}{l}1.817 \\
+i ?\end{array}$ & 451 L. 2 s. 8 d. & $9.020 \mathrm{~L}$. & $22 / 312$ \\
\hline Total & $\begin{array}{l}1.088 \\
+i ?\end{array}$ & 776 & $\begin{array}{c}1.898 ' 25 \\
+i ?\end{array}$ & $\begin{array}{c}3.911 ' 25 \\
+i ?\end{array}$ & $\begin{array}{c}2.546 \mathrm{~L} .10 \mathrm{~s} . \\
4 \mathrm{~d} .\end{array}$ & $50.920 \mathrm{~L}$. & 694 / 1.088 \\
\hline
\end{tabular}

En cursiva $=$ datos reconstruidos.

1. Acerca de esta partida, sólo conocemos la cosecha de algarrobas.

2. Alatara, Albaida, Árguinas, Cabezo, Cabezo Blanco, Cueva Santa, Hielto, Mas de Mar, Montes de Geldo y Reboll.

3. Bajo este epígrafe no sólo encontramos viñas, sino también algarrobos, higueras, alfalfa y tierra campa. 
Además de los abordados hasta el momento, podemos tomar en consideración un último aspecto más gracias a la información suministrada por el cuaderno de arrendamientos del año 1611. Nos referimos a la participación de moriscos de otras poblaciones próximas a Segorbe en el conjunto de la propiedad urbana y del dominio agrario arrendado durante la etapa comprendida entre el 1 de noviembre de 1610 y la misma festividad del año 1611. Como acabamos de ver, el conjunto de los bienes dejados atrás por los moriscos a finales de 1609 que pudo ser arrendado el año 1611 reportó a la administración del expolio un total de 491'5 libras en concepto de alquiler de propiedades urbanas más otras 2.546' 5 libras por el arrendamiento de la propiedad agraria. Estas dos cifras nos han permitido evaluar el valor de ambos dominios en unas 16.200 libras -la propiedad urbana- y entre 51, 64 y 80.000 libras -la rústica- si bien nos ha parecido más prudente situar el valor general de la propiedad agraria en unas 64.000 libras. En conjunto, pues, podría decirse que el valor de los bienes arrendados en 1611 por la administración del expolio de Segorbe podía haber rondado las 80.000 libras aproximadamente.

Valor de los arrendamientos suscritos por la administración del expolio segorbino en 1611 distinguiendo el origen de los antiguos propietarios moriscos

\begin{tabular}{|c|c|c|c|c|}
\hline & Valor propiedad urbana & $\%$ & Valor propiedad rural & $\%$ \\
\hline Cárrica & $0 \mathrm{~s}$. & & 12 L. 4 s. 10 d. & 0,5 \\
\hline Castelnovo & $0 \mathrm{~s}$. & & 9 L. 12 s. 0 d. & $0 ’ 4$ \\
\hline Geldo & $0 \mathrm{~s}$. & & 157 L. 3 s. 1 d. & $6 ' 2$ \\
\hline Navajas & $0 \mathrm{~s}$. & & 333 L. 10 s. 0 d. & $13 \prime 1$ \\
\hline Segorbe & 452 L. 4 s. 8 d. & $92^{\prime} 0$ & 2.030 L. 11 s. 9 d. & $79^{\prime} 6$ \\
\hline Soneja & $1 \mathrm{~L} .15 \mathrm{~s}$. & $0^{\prime} 4$ & $0 \mathrm{~s}$. & \\
\hline Sot & $0 \mathrm{~s}$. & & 3 L. 18 s. 8 d. & $0 ’ 2$ \\
\hline Xérica & 37 L. 10 s. 9 d. & $7 ' 6$ & $0 \mathrm{~s}$. & \\
\hline TOTAL & 491 L. 10 s. 5 d. & 100 & 2.546 L. 10 s. 4 d. & 100 \\
\hline
\end{tabular}

La tabla anterior permite apreciar el tremendo peso -esperable, por otra parte-de los moriscos propiamente segorbinos entre los antiguos propietarios de los inmuebles y predios arrendados en 1611. Este peso resulta ser-lógicamente- más evidente en el caso de la propiedad urbana, ya que las viviendas y dependencias subastadas para su alquiler anual estaban situadas todas ellas en la ciudad de Segorbe. Por ello mismo, no deja de ser interesante que 2 ó 3 moriscos de Xérica -todos ellos pertenecientes a la familia Razín- junto con un morisco de Soneja llamado Xabén poseyeran inmuebles que -una vez alquilados en 1611- representaron un $8 \%$ del valor global de los ingresos que el expolio obtuvo por este concepto. Las propiedades agrarias - por el contrario-se hallaban localizadas dentro de una vasta extensión de terreno que asimismo abarcaba términos de otras poblaciones cercanas. Esta es la razón que explica que un nada desdeñable $20^{\prime} 4 \%$ del valor de los predios rurales perteneciese a moriscos no segorbinos, entre los que destacan los antiguos habitantes de Navajas - propietarios de las tierras de labor de aquella localidad arrendadas en 1611-y los de Geldo. Las propiedades rurales 
de moriscos radicados en Cárrica, Castelnovo y Sot de Ferrer aportaron -como se veapenas un $1 \%$ del valor de los arrendamientos anuales a la administración del expolio.

\section{LA PARTIDA DE ALMAGRÁN, PARADIGMA DE LAS DIFICULTADES INTERPRETATIVAS Y DEL POTENCIAL INFORMATIVO DEL DOCUMENTO}

La información del cuaderno de arrendamientos de las antiguas propiedades moriscas correspondiente al período 1-XI-1610 a 1-XI-1611, hoy conservado dentro del expediente 10.118 de la sección Maestre Racional del Archivo del Reino de Valencia, contiene errores, deficiencias e imprecisiones. Lo verificaron y reiteraron en diversas ocasiones los inspectores de cuentas del regio patrimonio cuando revisaron sus datos el año 1618. También hemos podido constatarlo nosotros a través de un análisis exhaustivo de la fuente. Por tanto, el investigador que pretenda estudiar estos expedientes deberá hacerlo pertrechado de paciencia suma, tiempo casi infinito y sólidas herramientas conceptuales y metodológicas. Vaciar su contenido y sumar sus cifras con mayor o menor acierto no sólo no basta, sino que -incluso- puede resultar contraproducente si se hace con descuido, de manera incompleta, con la premura de quien tiene un plazo perentorio que cumplir y sin una idea precisa de la naturaleza del documento y de su potencial informativo. Trabajos así, más que una contribución al conocimiento histórico, constituyen un innecesario obstáculo para una tarea de enorme complejidad, que no precisa de ninguna perturbación adicional más para resultar extraordinariamente ardua.

Nuestra experiencia nos ha convencido de la pertinencia de comparar todos y cada uno de los cuadernos de arrendamientos conservados, si -en ausencia de los inventarios realizados después de la expulsión- se desea adquirir una visión lo más cabal y precisa posible de la propiedad morisca en Segorbe y su entorno rural a comienzos del siglo XVII. Pero también nos ha persuadido de la imposibilidad de llevar a cabo un estudio tal en el tiempo que habitualmente suele dedicarse a la composición de un artículo. Una investigación de estas características requeriría más bien el esfuerzo de una monografía o de una tesis doctoral. Aun así, quisiéramos ofrecer a nuestros lectores una corroboración explícita de cuanto hemos dicho, que sirva -al mismo tiempo- como aviso para navegantes a cuantos deseen acometer en el futuro el estudio pormenorizado del expolio segorbino. Para llevar a cabo esta especie de cata hemos escogido -por las razones que iremos exponiendo- una partida de la huerta segorbina -Almagrán-y hemos procedido a contrastar los arrendamientos de las antiguas propiedades moriscas que constan en los expedientes 10.118 -año 1611-y 10.119 -año 1612- de la sección Maestre Racional. Este procedimiento nos ha permitido verificar que, aunque la disparidad no haya sido excesiva, existen diferencias que podrían llegar a condicionar la correcta interpretación de la información reflejada en un cuaderno y en otro.

La primera constatación de la que debemos informar es la siguiente: ni el número de propietarios moriscos, ni el de sus propiedades o parcelas, ni la extensión de las mismas es el que podría obtenerse sumando uno a uno los asientos que integran el epígrafe 
titulado Almagrán del cuaderno de arrendamientos del año $1611^{82}$. Para establecer con exactitud estos tres aspectos ha sido necesario suprimir del recuento todo aquello que debía ser eliminado; añadir aquello que, aunque tendría que haber sido anotado por los escribanos, no consta en el documento; leer pacientemente el interrogatorio realizado por los coadjutores del Maestre Racional a los responsables de la administración del expolio; extraer las conclusiones que se derivan de sus respuestas dadas y determinar con precisión la cantidad que los arrendatarios cristiano-viejos de las antiguas propiedades moriscas de Almagrán satisficieron en concepto de peita al Real Patrimonio. Como puede apreciarse, el camino a seguir no ha sido precisamente rectilíneo, ni las etapas a cubrir han sido las que cabría haber esperado. Todo lo contrario. Ahora bien, la contrapartida a nuestros esfuerzos ha sido un grado de precisión que ningún otro procedimiento podía garantizar, ni siquiera el recuento minucioso y concienzudo de todos y cada uno de los asientos o ítems del cuaderno de arrendamientos.

En efecto, un trabajo paciente y escrupuloso con los asientos hubiera arrojado las siguientes cifras: 58 antiguos propietarios moriscos, 70 propiedades o parcelas -de las cuales está documentada la extensión precisa de 68- con una extensión global de $138^{\prime} 75$ hanegadas -a las que habría que añadir la de un moreral y la de una propiedad de superficie indeterminada- cuyo arrendamiento habría reportado un total de 116 libras 1 sueldo y 4 dineros al Real Patrimonio el año 1611. Sin embargo, los resultados correctos no son éstos, sino estos otros: 59 propietarios moriscos, 73 parcelas, $145^{\prime} 5$ hanegadas de extensión global y 118 libras, 14 sueldos y 8 dineros obtenidos por el arrendamiento de todas estas propiedades sitas en Almagrán ${ }^{83}$. El recorrido que hemos debido seguir hasta alcanzar estas cifras ha sido -lo hemos indicado ya- tortuoso. En primer lugar, hubo que eliminar del recuento el item 170 -es decir, las moreras de Alabit ${ }^{84}$ - el 172 - un yermo con 2 moreras perteneciente a la Aljama ${ }^{85}$ - y el 175 -2 hanegadas de tierra de Pedro Benazar, yerno de Rodero $^{86}$ - por indicarse explícitamente en el documento que estas 3 propiedades habían sido incluidas por error en la partida de Almagrán. Esta operación dejó el número de parcelas reducido a las 70 que hemos indicado. A continuación hubo que reponer el ítem 175 del cuaderno de arrendamientos de 1611 al comprobar que -pese a lo afirmado entonces por el escribano- la propiedad de 2 hanegadas de Pedro Benazar sí se hallaba dentro de los límites de Almagrán, tal y como corroboraba el item 331 del cuaderno de arrendamientos de $1612^{87}$. Este mismo

82. ARV: Maestre Racional, exp. 10.118, cuaderno de arrendamientos, fols. $13 \mathrm{v}-20 \mathrm{r}$.

83. Estos son los resultados que constan en el cuadro pormenorizado del epígrafe anterior donde ofrecemos los datos de que disponemos para cada una de las partidas o grupos de partidas del agro segorbino.

84. ARV: Maestre Racional, exp. 10.118, cuaderno de arrendamientos, fol. $19 \mathrm{r}$.

85. ARV: Maestre Racional, exp. 10.118, cuaderno de arrendamientos, fol. $19 \mathrm{r}$.

86. ARV: Maestre Racional, exp. 10.118, cuaderno de arrendamientos, fols. 19 r-19 v. Aunque es probable que Pedro Benazar fuera yerno del albañil Pedro Rodero que también poseía una parcela de 3 hanegadas en Almagrán, es posible que -en realidad- fuese yerno del morisco Jerónimo Rodero, dueño de una casa situada en la $\mathrm{C} /$ del Albellón.

87. ARV: Maestre Racional, exp. 10.119, cuaderno de arrendamientos, fol. 95 r. 
documento precisaba en su item 315, que el item 136 del cuaderno de 1611 -4 hanegadas de tierra pertenecientes a Pedro Taher carabacica- no era una única parcela, sino -en realidad- dos ${ }^{88}$. Efectuadas estas dos correcciones, el número de propiedades o parcelas arrendadas en 1611 había pasado a ser de 72 y el montante global alcanzado por los arrendamientos se había incrementado en 25 sueldos más, mientras el número de antiguos propietarios moriscos continuaba siendo de 58.

Un aspecto del cuaderno de arrendamientos del año 1611 nos inquietaba. Al asentar la cantidad concertada en cada una de las operaciones, el escribano del expolio había anotado sistemáticamente que cada una de aquellas sumas había sido satisfecha en concepto de arrendament y per la peyta. De esto se deducía claramente que la cifra que constaba en el cuaderno era el resultado de haber sumado el precio concertado para el arriendo a la cantidad correspondiente a la peita anual. Puesto que el escribano sólo había asentado una única cifra, resultaba completamente imposible discernir qué parte podía corresponder al arrendamiento y qué otra a la peita. Sin embargo, en el caso de la partida de Almagrán, una mano diferente había añadido a posteriori el valor de la peita para cada una de las parcelas arrendadas. Aunque ahora podíamos determinar el montante de este impuesto para la partida de Almagrán, el problema inicial continuaba persistiendo, dado que ignorábamos si la peita estaba comprendida en la cantidad inicialmente anotada por el escribano o si -por el contrario- a esta había que sumar aquella otra que había sido añadida posteriormente por una segunda mano. Para despejar nuestras dudas en la medida de lo posible tuvimos que acudir al qüern de dubtes del expediente donde los coadjutores del Maestre Racional debían reflejar todo cuanto necesitase ser esclarecido antes de la clausura de los libros de un determinado ejercicio contable. No nos cabía ninguna duda de que la suma correspondiente a la peita de la partida de Almagrán había sido añadida por orden de algún coadjutor y quisimos comprobar a qué tipo de interrogatorio se había sometido a los responsables del expolio segorbino.

Nuestras sospechas resultaron completamente fundadas. En el punto $\mathrm{n}^{\mathrm{o}} 11 \mathrm{del}$ pliego de dudas aparecía el interrogatorio al que fueron sometidos el clavario Joaquín Larralde y Bastán, el administrador Mateo Bosch y el notario José Taix por los inspectores de cuentas del Real Patrimonio entre finales de abril y principios de mayo de $1618^{89}$. Según su costumbre, Larralde fue directamente al grano. Aclaró que -aunque el cuaderno de arrendamientos de 1611 pudiera dar a entender otra cosa- él no había cobrado más peita que la de la partida de Almagrán. Hubiera podido exigirla íntegramente a todos los arrendatarios si así se lo hubieran indicado los administradores Bosch y Guevara, y lo hubiera certificado cualquiera de los notarios del expolio. Pero, con la excepción de la partida de Almagrán, nadie le había pasado una lista certificada

88. ARV: Maestre Racional, exps. 10.118 y 10.119, cuaderno de arrendamientos, fols. 15 r y 94 r.

89. La acumulación de trabajo que padecía la inspección de cuentas del regio patrimonio explica perfectamente que pudieran transcurrir 6 años o más -como sucede en este caso- entre la finalización de un ejercicio contable -noviembre de 1611-y la clausura definitiva de las cuentas -finales de 1618- con la correspondiente exigencia de responsabilidades por parte de la curia del Maestre Racional. 
de las cantidades a percibir, ni nadie le había exigido que las cobrase. La razón de esta diferencia estribaba -según el testigo- en que tradicionalmente los propietarios moriscos de Almagrán habían pagado su peita a la Aljama y no a la ciudad de Segorbe, de modo que, desaparecida aquella tras la expulsión, la percepción de la peita de Almagrán correspondía a la administración del expolio. Larralde asumió plenamente su responsabilidad en este punto. Señaló que, aunque algunos arrendatarios cristianoviejos de Almagrán nunca le habían abonado cantidad alguna en concepto de peita, él estaba dispuesto a hacerse cargo de cuanto pudiera adeudarse al expolio, pagándolo de su retribución como clavario ${ }^{90}$.

Mateo Bosch fue interrogado el día 5 de mayo de 1618. Tal y como había hecho Larralde, Bosch enfatizó la precariedad de medios y de instrucciones precisas con que había tenido que llevar a cabo sus obligaciones como administrador del expolio. Dijo no haber dispuesto de información alguna ni saber nada concreto acerca de la percepción de las peitas, excepción hecha de la partida de Almagrán, que debía pagarse a razón de 6 sueldos y 8 dineros la hanegada. Los moriscos segorbinos -como causa habientes de los mudéjares- estaban obligados a su satisfacción a la Aljama para que esta pudiera reunir cierta cantidad de dinero que el rey Martín I el Humano había destinado a la obra de la Cartuja de Valdecristo. A cambio de esta carga, los mudéjares segorbinos habían recibido permiso para adquirir tierras fuera de los lindes de Almagrán, posibilidad que antes de haberse otorgado esta licencia tenían completamente vedada. La administración del expolio - por otra parte- no había comenzado a exigir la peita de Almagrán hasta el ejercicio 1-XI-1610 a 1-XI-1611, ya que durante el ejercicio anterior -1-XI1609 a 1-XI-1610 - la gran mayoría de las antiguas propiedades moriscas de Almagrán no había sido arrendada, sino que su explotación había sido concedida en aparcería, es decir, mediando acuerdo de reparto de la cosecha. Reconocía Bosch que una parte de la peita del año 1611 todavía no había sido cobrada a los antiguos arrendatarios, pero señalaba que, conociendo la extensión de las parcelas arrendadas y la cantidad a pagar por hanegada, resultaría sencillo efectuar el cálculo de la deuda ${ }^{91}$.

El testimonio del notario José Taix corroboró hasta cierto punto las palabras de Larralde y de Bosch. Era verdad que la peita que debían satisfacer los moriscos $-\mathrm{y}$ después los arrendatarios de sus tierras- se calculaba a razón de 6 sueldos y 8 dineros la hanegada. Pero no era menos cierto que los administradores y clavario, en atención a la suerte que hubiera corrido el arrendamiento, habían exigido en ocasiones menos dinero del fijado de antemano para las peitas. Esta irregularidad en el procedimiento había sido detectada por los coadjutores del Maestre Racional. Los inspectores habían conminado a Taix para que anotase explícitamente la peita de cada una de las propiedades moriscas arrendadas en Almagrán el año 1611 con el fin de calcular la cantidad exigible a Bosch, Guevara y Larralde. La cantidad resultante de esta operación fue un

90. ARV: Maestre Racional, exp. 10.118, fol. 29 r.

91. ARV: Maestre Racional, exp. 10.118, fols. 29 r- 29 v. 
total de 48 libras, 9 sueldos y 11 dineros ${ }^{92}$. Taix añadió -por último- haber informado al procurador del Duque de Cardona tanto de lo que se adeudaba por las peitas de Almagrán cuanto por las peitas de las restantes partidas, y dijo saber que el representante de D. Enrique Folch de Cardona había perdonado estas cantidades a los antiguos arrendatarios.

La información suministrada por Larralde, Bosch y Taix en el qüern de dubtes es sencillamente crucial, no sólo para interpretar correctamente las particularidades de la administración del expolio, sino también para entender ciertos rasgos del pasado agrario segorbino y ciertos detalles acerca del comportamiento de la comunidad mudéjar -más tarde morisca- de Segorbe. Reparemos, por el momento, en el cálculo de la peita de Almagrán. Puesto que cada hanegada de tierra en Almagrán estaba gravada con 6 sueldos y 8 dineros de peita, y conocemos tanto la peita que debieran haber pagado cada uno de los arrendatarios cristiano-viejos de esta partida, cuanto la peita global que debiera haberse cobrado en 1611 a tenor del número de hanegadas arrendadas, podemos calcular con precisión la extensión de tierra de aquellas parcelas en las que no consta y efectuar un cálculo preciso del conjunto de hanegadas arrendadas ese año.

El moreral de Luis Çafán, con sus 10 sueldos de peita, debía rondar la hanegada y media, mientras que la parcela que fue de Juan Çafar tendría una hanegada, a tenor de la peita con que estaba cargada de 6 sueldos y 8 dineros $^{93}$. Así pues, si a las 138'75 hanegadas de nuestro primer recuento añadimos 2 hanegadas más de la parcela de Pedro Benazar -que definitivamente formaba parte de Almagrán- 1'5 hanegadas del moreral de Luis Çafán y otra de la parcela de Juan Çafar, obtenemos un total de 143'25 hanegadas. Ahora bien, como el conjunto de la peita teóricamente satisfecha en 1611 se elevaba a 48 libras 9 sueldos y 11 dineros, podemos deducir-dividiendo esta cifra por 6 sueldos y 8 dineros- que el número global de hanegadas arrendadas en 1611 debió elevarse a $145^{\prime}$ '5. Esto significa -ni más ni menos- que el cuaderno de arrendamientos ha pasado por alto una propiedad más de 2'25 hanegadas que, aunque debió ser arrendada, no figura en el cuaderno, impidiéndonos esta circunstancia averiguar a quién perteneció y quién la arrendó ${ }^{94}$. Este es el motivo por el cual hemos añadido un propietario morisco - de identidad desconocida- y una parcela más - de arrendatario indeterminado- a nuestro cómputo final. Queda este definitivamente establecido del siguiente modo: el año 1611, en la partida de Almagrán, fueron arrendadas 73 parcelas pertenecientes a 59 antiguos propietarios moriscos que -todas juntas- sumaban 145'5 hanegadas. Estas 73 parcelas fueron arrendadas en forma de 53 lotes a un total de

92. ARV: Maestre Racional, exp. 10.118, fol. 29 v. Como era su obligación, esta cantidad fue anotada como un ingreso más en el llibre de rebudes del año 1611, donde aparece registrada de manera oficial. ARV: Maestre Racional, exp. 10.118, fol. 2 r.

93. ARV: Maestre Racional, exp. 10.118, cuaderno de arrendamientos, fols. 14 r y 19 r.

94. De hecho, en el cuaderno de arrendamientos del año 1611 falta el item 166. Aunque este asiento nunca fue cumplimentado, el espacio que se dejó reservado para anotar los datos del arredamientos apunta hacia la existencia de alguna antigua propiedad morisca de la que dar cuenta que, por el motivo que fuere, fue finalmente omitida. ARV, Maestre Racional, exp. 10.118, cuaderno de arrendamientos, fol. $18 \mathrm{v}$. 
41 arrendatarios cristianos. Los beneficiarios cristiano-viejos pagaron un total de 118 libras 14 sueldos y 8 dineros por el arrendamiento más otras 48 libras 9 sueldos y 11 dineros en concepto de peita a la administración del expolio. Las tierras arrendadas en Almagrán el año 1611 probablemente poseyeran un valor cercano a las 2.300 ó 2.400 libras y representasen, por tanto, un 3'7\% del valor de las tierras moriscas cedidas en arriendo ese año y un 3\% del valor global de las posesiones rústicas y urbanas de los moriscos expulsos ${ }^{95}$.

\section{LOS PROPIETARIOS MORISCOS DE LA PARTIDA DE ALMAGRÁN: UN SONDEO RESTRINGIDO, AUNQUE ALECCIONADOR}

De siempre, el minifundismo ha constituido una de las características esenciales del campo segorbino. Las pequeñas explotaciones abundan dentro y fuera de la ciudad, en sus alrededores y en los aledaños del sistema hidráulico que la circunda. Los predios comienzan a ganar extensión en dirección a las laderas montuosas, aunque sin alcanzar nunca grandes dimensiones. Allí, las hortalizas, legumbres, frutales, olivos y cereales de alta calidad dejan paso a las higueras, vides, algarrobos, olivares viejos y granos de inferior calidad. De entre todas las partidas del agro segorbino, Almagrán debió ser una de las de parcelario más tupido. Sería difícil imaginarlo de otro modo. Localizada en pleno corazón de la huerta de Segorbe, justo donde la lucha por la tierra había sido siempre más encarnizada, sus parcelas formaban un abigarrado enjambre de formas, tamaños y variedades vegetales. Durante generaciones, los musulmanes segorbinos habían tenido prohibido adquirir tierras más allá de los confines de esta partida. Esta es -al menos- la información que Bosch, Larralde y Taix proporcionaron a los inspectores del regio fisco el año 1618. Los cuantiosos gastos ocasionados por la fundación (1385) y la erección (1405) de Valdecristo - prosiguieron- habrían contribuido a dar un vuelco a la situación. A cambio de una cuantiosa peita para la obra de la Cartuja, las restricciones existentes desaparecieron y los mudéjares alcanzaron el derecho a adquirir tierras en otras áreas del agro segorbino.

Aunque no podemos estar completamente seguros de que el testimonio de los responsables del expolio responda fielmente a la realidad de los hechos, disponemos algunas pruebas documentales que apuntan en esa dirección. La primera de ellas es la concesión a perpetuidad de las peitas que debía satisfacer tanto la comunidad cristiana como la aljama musulmana de Segorbe a la Cartuja de Valdecristo. La decisión fue adoptada por el rey Martín I el Humano en una fecha indeterminada, probablemente no demasiado distante del 28 de diciembre de 1406, día del fallecimiento de su esposa, la reina María de Luna, condesa de Segorbe ${ }^{96}$. La aljama mudéjar segorbina estaba gravada entonces con una peita anual de 5.000 sueldos, mientras que la comunidad cristiana -mucho más numerosa- debía abonar por el mismo concepto no más de 4.000

\footnotetext{
95. Continuamos calculando el valor de las propiedades multiplicando por 20 el precio del arrendamiento anual.

96. PÉreZ GarcíA, P.: Op. cit., págs. 100-122.
} 
sueldos cada año. Puesto que la reina María había dejado a la Cartuja un legado de 5.000 florines en su testamento y su esposo -y albacea- andaba precisado de aquella cantidad, se llegó al acuerdo de entregar todos los años a Valdecristo la peita íntegra de los mudéjares segorbinos en concepto de intereses o renta perpetua a cambio del legado de los 5.000 florines. Los 5.000 sueldos de la peita mudéjar se repartirían del siguiente modo: 3.600 deberían ser destinados a la fábrica de la Cartuja y los 1.400 restantes serían de libre disposición ${ }^{97}$.

El primer año del que tenemos constancia de haberse realizado el abono de los 5.000 sueldos en las condiciones indicadas es $1412^{98}$. Ya entonces el rey Martín tenía contraída una importante deuda con Aparici Martí. El soberano había concertado con él un préstamo a carta de gracia de 33.000 sueldos, a un interés anual de 2.200 sueldos $^{99}$. Para satisfacer esta cantidad, el monarca situó su pago sobre parte de la peita de los cristianos de Segorbe y decidió entregar los 1.800 sueldos restantes a la Cartuja ${ }^{100}$. Ignoramos si en algún momento se saldó la deuda con los herederos de Aparici Martí $\mathrm{y}$, por tanto, no podemos determinar hasta cuándo continuaron abonándose estos 2.200 sueldos anuales. Es evidente, sin embargo, que tanto la peita de los mudéjares -de los moriscos, posteriormente- cuanto la peita de los cristianos viejos segorbinos - de una parte de ella, al menos- continuó abonándose a la Cartuja de Valdecristo probablemente hasta el final del régimen foral ${ }^{101}$.

Sin embargo, no todo es tan evidente como creían los responsables del expolio. De hecho, hay motivos más que sobrados para preguntarse si la fijación de una peita tan onerosa como 6 sueldos y 8 dineros por hanegada a comienzos del siglo XV -y, en su caso, la licencia otorgada a los mudéjares segorbinos para que pudieran adquirir tierras más allá de los confines de Almagrán- fue el resultado de la materialización de las cláusulas testamentarias de la reina María de Luna a favor de Valdecristo o si -más bien- pudo ser un asunto relacionado con la falta de liquidez del nieto de los reyes Martín y María, D. Federico de Luna, nuevo señor de Segorbe desde mediados del

97. ARV: Maestre Racional, exp. 9.667 (1426), fol. 3 r.

98. ARV: Maestre Racional, exp. 9.656 (1412), fols. 25 v- 26 r.

99. Las referencias al préstamo concertado con Aparici Martí pueden encontrarse en ARV: Maestre Racional, exps. 9.667 (1426), fol. 3 v, 9.669 (1428), fol. 65 r y 9.694 (1477), fol. 66 r.

100. La decisión de entregar 1.800 sueldos de la peita de los cristianos de Segorbe a Valdecristo debió adoptarse poco más o menos al mismo tiempo que la donación de los 5.000 sueldos de la peita de los musulmanes, puesto que ambos abonos constan - uno detrás del otro- en los fols. $25 \mathrm{v}$ a $26 \mathrm{r}$ del exp. 9.656 (1412) de la sección Maestre Racional del ARV.

101. La desaparición de cualquier referencia a las peitas segorbinas en los expedientes contables del Real Patrimonio correspondientes a los primeros años del dominio del Infante Fortuna o a la etapa del secuestro del Ducado tras el fallecimiento en 1576 del duque Francisco Ramón, no significa -como ha llegado a suponerse- que la ciudad quedara exenta del pago de la peita debido a la munificencia de los duques de Segorbe. Esta ausencia obedece -más bien- a la definitiva revocación de una práctica contable que ya no tenía razón de ser, pues ya no era necesario reservar un espacio para las peitas, reiterando año tras año que estos derechos estaban cedidos a perpetuidad a Valdecristo. 
año $1409^{102}$. En efecto, el joven Federico recibió un patrimonio seriamente afectado por las donaciones de sus abuelos. Si quedó privado de una suma tan considerable como los 5.000 sueldos anuales de la peita de los mudéjares, parece razonable pensar que el Conde decidiera apretar las clavijas a sus vasallos musulmanes. Sabemos que una sentencia pronunciada entre 1410 y 1412 por el procurador general del condado y alcaide del castillo de Segorbe, Joan de Sent Feliu, había «condenado» a los mudéjares segorbinos al pago de una peita suplementaria de 500 sueldos anuales, además de los 5.000 que se entregaban a Valdecristo ${ }^{103}$. Esta «sanción», más que instrumento de la justicia, debió ser uno de los mecanismos adoptados por la administración condal para incrementar las rentas señoriales. Ahora bien, más allá del afán recaudatorio del Conde de Luna, la imposición de este gravamen extraordinario a la aljama segorbina proyecta un rayo de incertidumbre sobre el testimonio prestado por los responsables del expolio el año 1618. ¿Pudo ser entonces $-\mathrm{y}$ no tanto en los meses que siguieron al fallecimiento de María de Luna- cuando, entre las fórmulas aplicadas para el cobro de estos 500 sueldos, los propietarios de Almagrán vieron incrementadas sus peitas hasta $6^{2 / 3}$ sueldos la hanegada?

En estos momentos no puede darse una respuesta rotunda a este interrogante. Tampoco podemos corroborar la contrapartida que supuestamente habría permitido a los propietarios de Almagrán adquirir tierras fuera de los límites de la partida a cambio de una carga impositiva tan elevada. Con todo, no parece inapropiado situar en Almagrán el epicentro - uno de los epicentros, al menos- del dominio agrario de los mudéjares segorbinos. Es verosímil que Almagrán fuera no sólo uno de los dominios de más antiguo e intenso cultivo del entorno rural de la capital del Condado de Luna, sino también uno de los espacios donde los musulmanes pudieron quedar constreñidos tras las revueltas mudéjares contra el rey Jaime I. El interés que despierta su estudio no necesita, pues, justificación. Resulta evidente, no obstante, que la elección de Almagrán como base para un sondeo sobre la propiedad rural morisca y sobre su destino durante los años que siguieron a la expulsión obedece también al carácter abordable de la información contenida en la fuente y al hecho de disponer de un elemento de control y contraste tan preciso como las peitas allí satisfechas, a razón de 6 sueldos y 8 dineros la hanegada. Con todos estos instrumentos trataremos de abrir una ventana desde donde arrojar nueva luz sobre la realidad social y económica de los moriscos segorbinos en los momentos previos a la expulsión.

Los 59 propietarios moriscos de Almagrán cuyas tierras fueron arrendadas el año 1611 eran -todos ellos- minifundistas. No sólo poseían extensiones de tierras que apenas rozaban las 2'5 hanegadas de promedio, sino que -además- esta pequeña propiedad no se hallaba concentrada, sino dispersa en pequeñas parcelas, ninguna de las cuales solía alcanzar, por término medio, las 2 hanegadas. Trece de estos propietarios

102. PÉrez García, P.: Segorbe..., pág. 127.

103. ARV: Maestre Racional, exp. 9.656 (1412), fol. 5 r. Esta peita extraordinaria de 500 sueldos anuales fue cobrada, al menos, hasta finales del siglo XV, según hemos podido constatar documentalmente. 
-el 22\% - no poseía más que 1 hanegada de tierra en Almagrán, mientras que sólo 5 -el 8'5\%-disponían de 2 ó 3 parcelas con las que habían conseguido reunir poco más de 5 hanegadas. El mayor propietario morisco de Almagrán era Pedro Tallí, apodado el Viejo, dueño de 3 parcelas que sumaban un total de 7 hanegadas ${ }^{104}$. Entre todas las partidas de la huerta segorbina, Almagrán era -en conjunto- la de parcelario más pequeño. Sólo los diminutos huertos que salpicaban el trazado urbano de Segorbe ${ }^{105} \mathrm{y}$ las dos parcelas documentadas de la partida de Marroyo resultaban ser más pequeñas que las propiedades moriscas de esta partida. En líneas generales, podría afirmarse que una parcela media en Almagrán equivalía a poco más de 2/3 partes de una parcela media de tierra de huerta y a sólo $1 / 3$ de una parcela media de secano ${ }^{106}$.

\section{Los 59 Antiguos propietarios moriscos de la partida de Almagrán}

\begin{tabular}{|c|c|c|c|c|c|}
\hline Acén, Alejo & $2 \mathrm{~h}$. & Desconocido & $2 ’ 25 \mathrm{~h}$. & Morera (o Chovi) & $1 ' 5 \mathrm{~h}$ \\
\hline Acén, José & $3 \mathrm{~h}$. & Fetes & $2 \mathrm{~h}$. & Morcillo, Jerónimo el borde & $4 \mathrm{~h}$. \\
\hline Acén provecho & $3 \mathrm{~h}$. & Fusta, Lope de & $2 \mathrm{~h}$. & Motaher, Luis & $3 \mathrm{~h}$. \\
\hline Aitoni, Francisco & $1 \mathrm{~h}$. & Gonzalet & 3 h. (2) & Palomo, Pedro & $2 \mathrm{~h}$. \\
\hline Alabit & 5 h. (2) & Iñat, Juan (herrero) & $1 \mathrm{~h}$. & Patarni & $2 \mathrm{~h}$. \\
\hline Alabori, Pedro & $4 \mathrm{~h}$. & Izquierdo / Taher & $1,5 \mathrm{~h}$. & Patarni, Gaspar & $3 \mathrm{~h}$. \\
\hline Aleixandre & $1 \mathrm{~h}$. & Izquierdo & $2 \mathrm{~h}$. & Puntero & 5 h. (2) \\
\hline Algepsero, Luis & $2 \mathrm{~h}$. & Izquierdo el moreno & $2 \mathrm{~h}$. & Puntero el albardero & $1 \mathrm{~h}$. \\
\hline Alturi & 4 h. (2) & Izquierdo, padre e hijo & $2 ’ 25 \mathrm{~h}$. & Razín, Juan tercer & $3 \mathrm{~h}$. \\
\hline Barber & $1 \mathrm{~h}$. & Izquierdo, Jerónimo pajarico & $1 \mathrm{~h}$. & Rodero, Pedro (albañil) & $3 \mathrm{~h}$. \\
\hline Benazar, Juan ó Pedro & $2 \mathrm{~h}$. & Izquierdo, Pedro & $3 \mathrm{~h}$. & Sangarrén, Pedro & $1 ' 5 \mathrm{~h}$ \\
\hline $\begin{array}{l}\text { Benazar, Pedro el cojo } \\
\text { (yerno de Rodero) }\end{array}$ & 5 h. $(2)$ & Jabari, Francisco & $1 ' 5$ & Santo, Joan & $2 \mathrm{~h}$. \\
\hline Benazar buey hermoso & $1 \mathrm{~h}$. & Juneda & $1 ' 5 \mathrm{~h}$. & Taher, Jaume & $1 \mathrm{~h}$. \\
\hline Borrido, Francisco & 4 h. (2) & Marrán, Miguel & 3'5 h. & Taher, Pedro & $1 ' 5 \mathrm{~h}$ \\
\hline Çafán & $1 \mathrm{~h}$. & Mesclón, hijo de & $1,5 \mathrm{~h}$. & Taher, Pedro carabacica & 4 h. (2) \\
\hline $\begin{array}{l}\text { Çafán, Luis el viejo } \\
\text { (pelaire) }\end{array}$ & $\begin{array}{c}2 \mathrm{~h} .+ \text { un more- } \\
\text { ral de } 1^{\prime} 5 \mathrm{~h} .\end{array}$ & Mesclón, Pedro & $1 \mathrm{~h}$. & Tallí, Pedro el viejo & 7 h. (3) \\
\hline $\begin{array}{l}\text { Çafar, Juan bolota } \\
\text { (sastre) }\end{array}$ & $1 \mathrm{~h}$. & Mesclón el viejo & $3 \mathrm{~h}$. & Torrejano & $1 \mathrm{~h}$. \\
\hline Casim & 4 h. (2) & Moigh el cantarero & 5 h. (2) & Tunici el sordo & $3 \mathrm{~h}$. \\
\hline Costal & $1 \mathrm{~h}$. & Montani, viuda & 2 h. (2) & Tunici el tuerto & 4 h. (2) \\
\hline Chau-chau & $1,5 \mathrm{~h}$. & Montani, Jeroni & $2 \mathrm{~h}$. & & \\
\hline
\end{tabular}

La extensión en hanegadas // entre paréntesis el $n^{\circ}$ de parcelas cuando este sea superior a 1 .

104. ARV: Maestre Racional, exp. 10.118, cuaderno de arrendamientos, items 137, 151 y 153, fols. 15 r y $17 \mathrm{r}$.

105. A pesar del altísimo valor alcanzado por los terrenos urbanos, todavía hoy es posible contemplar pequeños huertos cultivados dentro de la ciudad de Segorbe.

106. Nos referimos siempre - por descontado- a las propiedades de los moriscos expulsos que fueron arrendadas el año 1611. 


\section{Arrendatarios cristiano-viejos de antiguas parcelas moriscas de la partida de Almagrán: 41 en 1611 y 38 en 1612}

\begin{tabular}{|c|c|c|}
\hline Arrendatarios en 1611 y 1612 & Arrendatarios en 1611 & Arrendatarios en 1612 \\
\hline Aliaga, Jaime $3 \mathrm{~h}(1)-3 h(1)$ & Abséñez, Francisco 1 h (1) & Cirati, Martín 3 h (1) \\
\hline Andrés, Antón 3 h (2) - 1 h (1) & Alcoy, Miguel 3 h (1) & Covos, Joan 10 h (5) \\
\hline Benafer, Jaime $3 \mathrm{~h}(1)-3 h(1)$ & Artieda, Pedro 2 h (1) & Escrig, Miguel 1 h (1) \\
\hline Benet, Salvador 4'5 h (3) $-4^{\prime} 5 h(3)$ & Benafer, Francisco 2 h (1) & Escrig, Pedro 3 h (1) \\
\hline Bernia, Jerónimo 3 h (1) $-7 h(2)$ & Bosch, Juan $1 \mathrm{~h}$ (1) & Fabra, Agustín 1 h (1) \\
\hline Capilla, Vicente $4 \mathrm{~h}(2)-4 h(2)$ & Castelló, Vicente 3 h (1) & Feliu, Pedro (mosén) 4 h (2) \\
\hline Cervera, Jaime 8' 5 h (4) - 4'5 h (5) & Ferrins, Agustín 4'5 h (3) & Gallart, José 2'5 h (1) \\
\hline Costa, Esteban 12 h (6) - 9 h (5) & Ferrins, José 5’75 h (2) & Gil, Jacques 1 h (1) \\
\hline Desconocido 2'25 h (1) - 2'25 h (1) & Gómez, Gil 3'5 h (2) & Gómez, Andreu 4'5 h (5) \\
\hline Domingo, Francisco 1'5 (1) - 6h (4) & Gómez, Martín 3 h (1) & Montero, Miguel (menor) 2 \\
\hline García, Juan 4 h (2) - 5 h (3) & Hervás, Pedro (mayor) 1 h (1) & $h(1)$ \\
\hline Gascón, José 3 h (2) - 6 h (4) & Martín, Pedro Juan 3 h (1) & Navalón, Juan 3 h (1) \\
\hline Gómez, Juan 4'5 h (2) - 4'5 h (2) & Martínez, Francisco 2 h (1) & Pérez, Damián 3 h (2) \\
\hline Hernández, Francisco 3 h (1) $-3 h$ (1) & Mayor, Juan 2 h (1) & Perpiñán, Domingo 3 h (1) \\
\hline Hernández, Sebastián 1 h (1) $-3 h$ (2) & Monsonís, Nicolás 4 h (2) & Polo, Domingo 3 h (1) \\
\hline Jiménez, Francisco 4 h (2) - 4 h (2) & Sales, José 9'5 h (5) & TOTAL $=14-44$ H (24) \\
\hline Jiménez, Pablo 4'5 h (2) $-3 h$ (1) & Tristany, Juan 2 h (1) & \\
\hline Magaña, Francisco 3'5 h (1) - 1 (1) & TOTAL $=17-51$ '25 н (26) & \\
\hline Magaña, Nicolás 4 h (3) - 4 h (3) & & \\
\hline Pérez, Domingo $4 \mathrm{~h}(1)-4 h(1)$ & & \\
\hline Pérez, Jaime 5'5 h (2) - 5 h (2) & & \\
\hline Povo, Francisco $2 \mathrm{~h}(1)-2 h(1)$ & & \\
\hline Rocafort, Jaime 5 h (3) - 6'5 h (3) & & \\
\hline Sancho, Pedro 1'5 h (2) -1 h (1) & & \\
\hline TOTAL $=24-94 ’ 25$ н (47) -96 H (52) & & \\
\hline
\end{tabular}

Sólo se han tomado en consideración las antiguas propiedades moriscas arrendadas en 1611 que volvieron a serlo en 1612. No hemos añadido la información acerca de un total de 11 hanegadas que fueron arrendadas por primera vez en 1612 .

$\mathrm{h}=$ hanegadas $/ /$ entre paréntesis $=\mathrm{n}^{\mathrm{o}}$ de antiguas parcelas moriscas $/ /$ en redonda los datos de 1611 y en cursiva los de 1612 .

La expulsión sólo modificó parcialmente esta situación. Los 53 nuevos lotes de tierras constituidos en 1611 por 41 nuevos arrendatarios cristiano-viejos, mejoraron desde luego los promedios, pero en modo alguno imprimieron un giro rotundo al minifundismo tradicional. Entre los arrendatarios de 1611 hubo quien llegó a superar ampliamente a Pedro Tallí el Viejo. Esteban Costa, por ejemplo, arrendó 6 parcelas en Almagrán y reunió un total de 12 hanegadas. Jaime Cervera consiguió hacerse con 4 antiguas propiedades moriscas que llegaron a sumar 8' 5 hanegadas. En líneas generales, sin embargo, las explotaciones medias reunidas por los cristianos viejos en 1611 
no pasaron de las $2^{\prime} 7$ hanegadas ${ }^{107}$. Pese a que los arrendatarios trataron por todos los medios de hacerse con parcelas limítrofes entre sí para poder generar economías de escala, cierto grado de dispersión continuó lastrando los beneficios y la productividad. En 1611 un lote de tierra de tipo medio en Almagrán seguía representando alrededor del $70 \%$ de un lote equivalente en la huerta segorbina, y poco más de un $30 \%$ de un lote semejante en el secano.

En términos absolutos es verdad que la expulsión propició un cierto grado de concentración de las explotaciones en manos de los cristianos viejos, pero no es menos cierto que, en términos relativos, las diferencias que siempre habían mediado entre las explotaciones de la partida de Almagrán y las restantes divisiones del agro segorbino se mantuvieron intactas. De hecho, el cuadro de los arrendatarios cristiano-viejos de antiguas propiedades moriscas en Almagrán en 1611 y 1612 podría ser el reflejo -inclusode un cierto desencanto, frustración o fracaso. Más de un $40 \%$ de los arrendatarios de 1611 -17 sobre 41- no volvieron a pujar por tierras de Almagrán al año siguiente. Un $60 \%$ volvió a intentarlo y nuevamente obtuvo un lote en esta partida. Ahora bien, no pocos de entre ellos - Jaime Cervera y Esteban Costa, sin ir más lejos-arrendaron en 1612 lotes sensiblemente inferiores a los que habían cultivado en 1611. Aunque también hubo quien pujó en 1612 por lotes de tierra algo mayores que en 1611, la extensión de tierra arrendada por las 24 personas que repitieron en Almagrán fue prácticamente idéntico: 94'25 hanegadas en 1611 y 96 en 1612. En 1612 irrumpieron en Almagrán 14 nuevos arrendatarios cristiano-viejos, pero no consiguieron llenar el vacío provocado por la ausencia de sus 17 predecesores. De las $145^{\prime} 5$ hanegadas cedidas en alquiler en 1611, sólo se volvieron a arrendar 140. Es posible que estas 5'5 hanegadas que faltan en el cuaderno de arrendamientos de 1612 fueran establecidas a enfiteusis, pero no podemos asegurarlo. En conjunto, no obstante, el año 1612 debieron ser arrendadas un total de 151 hanegadas ${ }^{108}$, cifra que, en cualquier caso, representa un incremento mínimo respecto de 1611, especialmente si tenemos en cuenta que el precio medio del arriendo por hanegada se había reducido un 11 ' $2 \%$ en $1612^{109}$.

107. Es decir, $145^{\prime} 5$ hanegadas divididas por 53 lotes de tierra.

108. El cuaderno de arrendamientos del año 1612 plantea problemas formales y de contenido en los que sería muy prolijo entrar ahora. Baste señalar ahora que este documento no nos ha permitido hacer un seguimiento absolutamente preciso de las propiedades arrendadas en 1611, dada la ambigüedad en la identificación de los antiguos propietarios y la disparidad en la extensión de la tierra reflejada en el cuaderno de 1612 respecto del correspondiente a 1611.

109. En efecto, si corregimos los errores, despejamos las incógnitas y sumamos uno a uno los asientos del cuaderno de 1612, obtenemos un total de 151 hanegadas de tierra arrendadas en la partida de Almagrán por un precio global de 109 libras, 12 sueldos y siete dineros, más una peita global de 50 libras, 6 sueldos y 8 dineros. Existe, no obstante, una clara disparidad entre la peita reflejada en el expediente contable normalizado y la cifra que podemos obtener sumando una a una las peitas devengadas por cada uno de los lotes de tierra arrendados. En el primer caso, asciende a 956 sueldos y 8 dineros -es decir, la peita que tendría que haberse satisfecho por 143'5 hanegadas- y en el segundo a 1.006 sueldos 8 dineros - esto es, la peita de 151 hanegadas. 
Resulta evidente, no obstante, que un estudio de la propiedad morisca restringido a la partida de Almagrán es insuficiente como vía de aproximación a la realidad social y económica de los moriscos segorbinos. Para intentar profundizar en ella hemos seguido un camino distinto. Aunque el procedimiento se ha revelado complejo, dadas las dificultades que supone la identificación de los individuos, hemos procurado seguir la pista a 46 de los 59 antiguos propietarios de tierras en la partida de Almagrán, precisamente aquellos que planteaban menos problemas y dudas. A continuación hemos sumado el precio que alcanzaron los arrendamientos de todas sus posesiones en el campo y en la ciudad el año 1611, y hemos tomado esta cifra como indicador del valor global de sus propiedades ${ }^{110}$. Finalmente, hemos distinguido 3 grandes grupos: A) moriscos propietarios de bienes en Almagrán y en otras partidas del agro segorbino cuyas posesiones fueron arrendadas por más de 100 sueldos en 1611, B) moriscos semejantes a los del grupo A cuyas posesiones fueron arrendadas por menos de 100 sueldos y C) moriscos que sólo tenían posesiones en Almagrán y cuyas propiedades -por cierto- a duras penas pudieron ser arrendadas en 1611 por más de 25 sueldos.

\section{Aproximación sociológica a los propietarios moriscos de la partida de Almagrán (datos completamente reconstruidos)}

\begin{tabular}{|c|c|c|c|c|c|}
\hline $\begin{array}{l}\text { Propietarios } \\
\text { Almagrán }\end{array}$ & $\mathbf{N}^{\mathbf{o}}$ & $\begin{array}{l}\text { Valor medio de } \\
\text { sus posesiones } \\
\text { en Almagrán }\end{array}$ & $\begin{array}{c}\text { Valor global de } \\
\text { sus posesiones } \\
\text { en Almagrán }\end{array}$ & $\begin{array}{c}\text { Valor medio de sus } \\
\text { propiedades en todo } \\
\text { Segorbe }\end{array}$ & $\begin{array}{c}\text { Valor global de sus } \\
\text { propiedades en todo } \\
\text { Segorbe }\end{array}$ \\
\hline Grupo A & 23 & $52 ' 5$ libras & 1.207 libras & 380'00 libras & 8.743 libras \\
\hline Grupo B & 12 & 37'1 libras & 445 libras & 53'25 libras & 639 libras \\
\hline Grupo C & 11 & 28’4 libras & 313 ibras & $28^{\prime} 45$ libras & 313 libras \\
\hline Total & 46 & 42'7 libras & 1.965 libras & 210'7 libras & 9.695 libras \\
\hline
\end{tabular}

Si nuestra reconstrucción no fuese desproporcionada del todo, podría afirmarse que los propietarios de tierras en la partida de Almagrán debieron constituir un grupo muy significativo dentro de la comunidad morisca de Segorbe, cuyas propiedades -en conjunto- podrían haber representado algo más del 12\% de la propiedad morisca global $^{111}$. Sus posesiones en Almagrán, sin embargo, apenas debieron alcanzar el 3\% del valor de la totalidad de la propiedad agraria morisca ${ }^{112}$. Los propietarios de Almagrán -por tanto- poseían abundante tierra fuera de los límites de esta partida y no pocos inmuebles dentro del Arrabal o en la propia ciudad de Segorbe. Con todo, no deja de ser esta una imagen sesgada por el peso de un 50\% de los propietarios de Almagrán -23 sobre 46- cuyas posesiones en la partida pudieron representar el $2 \%$ del valor de

110. Como de costumbre, para calcular el valor de la propiedad hemos multiplicado por 20 el precio del arrendamiento anual.

111. Hemos evaluado esta, a tenor de los arrendamientos de 1611, en unas 80.000 libras. Por tanto, (9.695 x 100) / 80.000.

112. (1.965 libras x 100) / 64.000 libras, cifra en que hemos evaluado el conjunto de propiedad agraria morisca en Segorbe. 
la tierra morisca y cuyos bienes pudieron alcanzar el $11 \%$ del valor conjunto de la propiedad morisca. Esta minoría -en cualquier caso- no puede ser considerada rica, sino sencillamente bienestante, ya que sus propiedades -individualmente hablando- no debieron superar las 380 libras de valor medio. Los propietarios moriscos más ricos de la partida de Almagrán fueron Francisco Aitoni y Lope de Fusta. El primero probablemente poseyera bienes por valor de 780 libras, mientras que el segundo debió disfrutar de un patrimonio cercano a las 700 libras ${ }^{113}$.

El 50\% restante era un grupo humilde dividido -como sabemos- en dos grandes categorías: quienes sólo poseían tierras en Almagrán y quienes -además- poseían terrenos en otras partidas del agro segorbino. Los segundos -claro está- superaban en patrimonio a los primeros. Las 53 libras que -como promedio-valían los bienes de cada uno de los 12 miembros del segundo grupo, casi duplicaban el valor medio de los bienes de los 11 componentes del segundo grupo, cifrado por nosotros en unas 28 libras. Pero además, las tierras que los segundos poseían en Almagrán -con 37 libras de valor medio- también excedían en valor -y de una manera muy clara-a las 28 libras en que hemos evaluado la propiedad de los primeros en esta partida.

\section{LOS CRÉDITOS Y LAS DEUDAS DE LOS MORISCOS}

Tanto como de sus casas, sus muebles, cosechas, ganado y heredades, la expulsión privó a los moriscos de los capitales que éstos habían prestado. Las actividades mercantiles y financieras de los moriscos han sido uno de los asuntos que la historiografía valenciana ha abordado en los últimos años, especialmente a partir de los trabajos pioneros de Eugenio Císcar ${ }^{114}$. Los moriscos nunca desdeñaron una buena iniciativa inversora. Quienes disponían de ahorros o recursos suficientes solían ser abordados por familiares, amigos, vecinos, conocidos o desconocidos dispuestos a venderles censales en unas condiciones más o menos jugosas. Los moriscos practicaban el préstamo de una manera tan normal -digámoslo así- como los cristianos. Hasta principios del siglo XVII, este tipo de operaciones de crédito se habían desarrollado con completa normalidad: se habían constituido los censales ante notario, establecido sus condiciones y garantías, pactado los intereses y los plazos, y -por lo común-se había dejado la puerta abierta para el fenecimiento de la deuda y el quitamiento del censal.

El decreto de expulsión de los moriscos valencianos vino a trastocar por completo este panorama. Muchos prestatarios debieron frotarse las manos pensando que un premio les había llovido del cielo. Los moriscos seguramente trataron de recuperar su dinero a la desesperada..., estaban dispuestos a recibir la mitad..., la cuarta parte... ¡quién sabe! Ante la perspectiva de librarse de sus deudas a precio de saldo, los cristianos viejos ofrecían cantidades ridículas a cambio de la cancelación de la deuda.

113. Según el registro de arrendamientos del año 1611, el propietario morisco más rico de cuantos aparecen documentados podría haber sido Pedro Palomo, con un patrimonio cifrado en unas 1.300 ó 1.400 libras.

114. CísCAR PALLARÉS, Eugenio: Moriscos, nobles y repobladores. Estudios sobre el XVII en Valencia, Valencia, 1993, especialmente págs. 13-113 y 117-225. 
Durante la semana que siguió a la publicación del decreto de extrañamiento debieron cerrarse no pocas operaciones de este tipo. Sin embargo, un decreto firmado por el Marqués de Caracena el 1 de octubre de 1609 acabó con ellas -al menos sobre el papel-al prohibir a los moriscos firmar quitamientos de censales ${ }^{115}$. La Corona proclamaba así su voluntad de neutralizar la zozobra del mercado de capitales, al tiempo que anunciaba de manera inequívoca su voluntad de convertirse legalmente en acreedora de los prestatarios cristiano-viejos.

El real fisco tardó algún tiempo en ponerse manos a la obra para averiguar el volumen de la deuda contraída por los cristianos viejos con los moriscos y en reclamar su devolución. Por lo que sabemos, durante 7 largos años después de la expulsión nadie importunó a los prestatarios. Esta circunstancia -nos atrevemos a imaginar-debió permitir a los más escrupulosos ir reuniendo dinero para hacer frente a sus obligaciones futuras, aunque también debió hacer creer a muchos que el paso de los días acabaría transformándose en olvido. En efecto, hasta comienzos del mes de agosto del año 1617 no comenzaron las reclamaciones. A partir de entonces, sin embargo, el comisario real Adrián Bayarte -tras haber invertido meses en pesquisas, interrogatorios y visitas a los notarios- comenzó a citar a todas aquellas personas que habían contraído deudas con los moriscos expulsos. Para llevar a cabo su trabajo, Bayarte dividió el Reino de Valencia en 10 grandes rutas o veredas y comenzó a recorrerlas en busca de su abultado censo de deudores. De sus pesquisas conservamos dos interesantes registros documentales que se custodian actualmente en la sección Maestre Racional del Archivo del Reino de Valencia ${ }^{116}$.

De alguna manera podría afirmarse que el segundo de estos dos registros completa y amplía el contenido del primero. Ambos fueron compuestos por orden de Bayarte. Antes de hacerlo personalmente, el comisario había pedido al clavario Mateo Bosch que reuniese los nombres de los prestatarios conocidos y tratase de determinar las operaciones de quitamiento de censales efectuadas de manera irregular o fraudulenta inmediatamente después de haberse dado a conocer el decreto de expulsión. El primero de los expedientes contiene, pues, el resultado de las pesquisas realizadas por Bosch ${ }^{117}$. El segundo -redactado entre el 7-VIII-1616 y el 11-XI-1617 con intervención directa de Adrián Bayarte- contiene una relación de prestatarios que podemos considerar ya exhaustiva o definitiva. Ahora bien, mucho más que un simple censo de deudas atrasadas - como, de hecho, era el cuaderno del clavario Bosch- la relación de Bayarte no sólo permite documentar la identidad de los prestatarios de los moriscos, sino también las operaciones financieras llevadas a cabo por el propio comisario entre 1616 y 1617.

115. DanVILA Collado, Manuel: Op. cit., pág. 348.

116. ARV: Maestre Racional, exps. 10.123 y 10.124.

117. El exp. 10.123 lleva por título Rebudes fetes per mi Matheu Bosch, clavari, en lo present any, les quals son per rahó de un memòrial que Adrian Bayarte, comissari real, m'entregà per a que cobràs de gents particulars per rahó de vendes, compres y barates fetes sens licència del senyor directe, averiguades per lo dit comssari segons consta per certificació de Joseph Taix notari a 24 de desembre del any 1616. La información acerca de la deuda ocupa los fols. $10 \mathrm{v}-12 \mathrm{v}$. 
Consistieron estas en la cancelación parcial de la deuda contraída mediante el inmediato abono de una parte de la misma y la constitución de un nuevo censal o debitorio a favor del Real Patrimonio con la cantidad restante ${ }^{118}$.

Se trata, pues, de dos registros de enorme interés para el estudio de un fenómeno no demasiado bien conocido como es la actividad crediticia de los moriscos. Estos dos documentos nos han permitido reconstruir no sólo las operaciones mercantiles y de préstamo -ventas no abonadas completamente al contado, constitución de censales y debitorios- que todavía estaban vivas en el momento de verificarse la expulsión, sino también todas aquellas cancelaciones y amortizaciones que se realizaron de manera fraudulenta, bien por no haberse notificado estas al señor directo de las propiedades objeto de transmisión o garantía de las hipotecas - es decir, al Real Secuestro del Ducado de Segorbe, a la Cartuja de Valdecristo o a cualquier otro- bien por haber contravenido la pragmática del Marqués de Caracena de 1 de octubre de $1609^{119}$. Evidentemente no constan en estos registros todas las deudas impagadas -y menos aún aquellas de pequeña monta que hubieran podido ser concertadas de palabra o de manera consuetudinaria - sino aquellas otras que los delegados regios consiguieron averiguar tras haber interrogado numerosos testigos y haber visitado no pocas notarías. Dado el número absolutamente insignificante de ventas aplazadas frente al peso abrumador de censales y debitorios documentados, hemos optado por no hacer ningún tipo de enojosa distinción técnico-jurídica en esta pequeña aproximación a la vertiente financiera de la comunidad morisca de Segorbe y su comarca.

Comenzaremos, pues, por establecer el volumen de los préstamos concertados con los moriscos de la llamada vereda de Segorbe. Tras paciente contraste entre ambos expediente y minucioso recuento de las cantidades reflejadas, podemos afirmar que los moriscos de esta vereda, el año 1609, tenían situados en forma de créditos a cristianos viejos un total de 91.459 sueldos y 5 dineros, es decir, 4.572 libras, 19 sueldos y 5 dineros ${ }^{120}$. Prácticamente la mitad de estos préstamos había sido concertada durante los 3 años que precedieron a la expulsión, es decir, entre 1607 y 1609. Esta circunstancia, unida al hecho de que ninguno de los títulos de deuda documentados sea anterior a $1600^{121}$, revela un apreciable grado de dinamismo dentro de la actividad crediticia de los moriscos, caracterizada por operaciones de crédito de una duración relativamente corta.

118. El exp. 10.124 se titula Comptes dels censals formats de deutes que christians devien a moriscos expulsos averiguats per lo comisari Bayarte en lo Regne de València dividit en 10 veredes, y conte del cobrat per dit Bayarte de contant de dits deutes que christians devien a moriscos, y ocupa los fols. $1 \mathrm{r}-34 \mathrm{v}$.

119. Vide nota 5 .

120. Ha sido necesario efectuar este recuento tan prolijo porque de las sumas universales que figuran en el exp. 10.123 (70.868 sueldos y 2 dineros) y en el exp. 10.124 (81.075 sueldos y 1 dinero) se habían descontado las cantidades abonadas para el fenecimiento parcial de la deuda, cuyo cómputo global -por cierto- no figuraba en ninguno de los folios de estos registros.

121. Ignoramos, no obstante, la fecha de constitución de censales por valor de 29.389 sueldos, es decir, de un tercio del capital prestado por los moriscos de la vereda segorbina. 


\section{Deuda censal contraída por cristianos viejos con moriscos de la vereda de Segorbe (distribución anual)}

\begin{tabular}{|c|c|c|}
\hline Población & Capital prestado & $\%$ \\
\hline ¿? & 29.389 s. 0 d. & $32{ }^{\prime} 1$ \\
\hline 1600 & 300 s. 0 d. & $0 ’ 3$ \\
\hline 1601 & 3.700 s. 0 d. & $4^{\prime} 0$ \\
\hline 1602 & 4.650 s. 0 d. & $5{ }^{\prime} 0$ \\
\hline 1603 & 2.070 s. 0 d. & $2 ’ 3$ \\
\hline 1604 & 1.945 s. 10 d. & $2 ’ 2$ \\
\hline 1605 & 3.188 s. 2 d. & 3,5 \\
\hline 1606 & 3.943 s. 4 d. & 4'3 \\
\hline 1607 & 10.880 s. 0 d. & $12^{\prime} 0$ \\
\hline 1608 & 19.414 s. 1 d. & $21 ' 2$ \\
\hline 1609 & 11.979 s. 0 d. & 13 '1 \\
\hline TOTAL & 91.459 s. 5 d. & 100 '0 \\
\hline
\end{tabular}

De alguna manera, este dinamismo parece quedar corroborado cuando conseguimos determinar que la cuantía media de los créditos concedidos apenas superaba las 42 libras. En efecto, las 108 operaciones de préstamo documentadas en los expedientes 10.123 y 10.124 arrojan un promedio de 42 libras y 7 dineros. De los prestamistas moriscos, conocemos la identidad de 69 e ignoramos la de $10^{122}$. En términos generales cada uno de estos 79 prestamistas habría otorgado créditos por valor de unas 58 libras a cristianos viejos. Desde luego, no todos los prestamistas moriscos respondían a un mismo patrón. Había quienes sólo habían concedido pequeñísimos créditos ${ }^{123}$, junto a quienes se habían desprendido de más de 100 libras ${ }^{124}$. Los mayores prestamistas eran dos vecinos de Geldo: D. Jaime Alpahuy o Alpagui, a quien el decreto de expulsión privó de 437 libras censales ${ }^{125}$-entre otras muchos bienes, seguramente- y Pedro Alpahuy, a quien Jerónimo Clemente, de Segorbe, y Francisco Pascual, labrador de Altura, dejaron a deber un total de 180 libras. El estudio pormenorizado de la deuda censal de la vereda de Segorbe revela que el crédito morisco -en su mayor parte- no procedía de las poblaciones más grandes -excepción hecha de la capital del Ducadosino villas de pequeño tamaño - Alfara, Geldo, Navajas o Eslida- y desvela que los grandes núcleos cristiano-viejos de la comarca -Segorbe, Altura y Alculas- fueron centros más bien consumidores de capitales moriscos.

122. Supondremos que estos 10 prestamistas desconocidos no sólo serían 10 individuos distintos, sino también que su identidad no coincidiría con ninguno de los 69 moriscos que conocemos.

123. Como Jerónimo Galip, que únicamente prestó 100 sueldos.

124. Como Pedro Mazuela de Gaibiel, Jerónimo Melón de Soneja, Francisco Payoni de Eslida, Juan Solet de Marines o Pedro Viari de Alfara.

125. Los prestatarios de Jaime Alpahuy eran los terciopeleros segorbinos Miguel Bernardo (117 libras) y Francisco Martín (260 libras), y el labrador de Altura Juan Marín de Cosme (60 libras). 


\section{Origen y destino geográfico de los capitales prestados por moriscos a cristianos} de la vereda de Segorbe

\begin{tabular}{|c|c|c|c|c|c|}
\hline Población & $\begin{array}{c}\text { Capital } \\
\text { prestado } \\
\text { por moriscos }\end{array}$ & $\%$ & Población & $\begin{array}{c}\text { Capital demandado } \\
\text { a moriscos }\end{array}$ & $\%$ \\
\hline ¿? & 10.974 s. 0 d. & $12^{\prime} 0$ & ¿? & 2.854 s. 10 d. & 3'1 \\
\hline Alfara & 5.570 s. 0 d. & 6’1 & Alcublas & 13.243 s. 6 d. & $14^{\prime} 5$ \\
\hline Ayódar & 1.040 s. 0 d. & 1'1 & Altura & 16.101 s. 4 d. & $17^{\prime} 7$ \\
\hline Benaguacil & 1.100 s. 0 d. & $1 ' 2$ & Castelnovo & 860 s. 0 d. & $0{ }^{\prime} 9$ \\
\hline Beselga & 800 s. 0 d. & $0 ’ 9$ & Caudiel & 7.235 s. 0 d. & $8{ }^{\prime} 0$ \\
\hline Castelnovo & 700 s. 0 d. & $0 ' 8$ & Begís & 4.058 s. 2 d. & $4^{\prime} 4$ \\
\hline Castielmontán & 900 s. 0 d. & $1 ’ 0$ & Benafer & 1.000 s. 0 d. & 1'1 \\
\hline Eslida & 11.043 s. 2 d. & $12^{\prime} 0$ & El Toro & 5.440 s. 0 d. & 6'1 \\
\hline Gabiel & 3.760 s. 0 d. & 4'1 & Gaibiel & 600 s. 0 d. & $0 ' 6$ \\
\hline Gátova & 600 s. 0 d. & 0 '7 & Geldo & 80 s. 0 d. & $0 ’ 1$ \\
\hline Geldo & 19.694 s. 0 d. & $21^{\prime} 5$ & Matet & 330 s. 0 d. & $0 ’ 3$ \\
\hline Gilet & 830 s. 0 d. & $0{ }^{\prime} 9$ & Pavías & 2.420 s. 0 d. & 2'6 \\
\hline Marines & 2.120 s. 0 d. & $2 ’ 3$ & Pina & 3.370 s. 0 d. & 3'6 \\
\hline Náquera & 480 s. 0 d. & $0 ’ 6$ & Puebla de Arenós & 360 s. 0 d. & $0 ’ 4$ \\
\hline Navajas & 10.707 s. 4 d. & $11 ' 7$ & Segorbe & 29.336 s. 7 d. & $32 ’ 1$ \\
\hline Olocau & 3.890 s. 0 d. & $4{ }^{\prime} 2$ & Xérica & 4.170 s. 0 d. & $4 ' 5$ \\
\hline Segorbe & 8.840 s. 11 d. & 9'6 & & & \\
\hline Sales & 480 s. 0 d. & $0 ’ 6$ & & & \\
\hline Soneja & 3.140 s. 0 d. & 3'4 & & & \\
\hline Vall de Almonacid & 950 s. 0 d. & $1 ' 1$ & & & \\
\hline Veo y Alcudia de Veo & 3.840 s. 0 d. & $4{ }^{\prime} 2$ & & & \\
\hline TOTAL & 91.459 s. 5 d. & $100 ' 0$ & TOTAL & 91.459 s. 5 d. & $100^{\prime} 0$ \\
\hline
\end{tabular}

La historia social de los moriscos valencianos, mucho más que por el préstamo, estuvo caracterizada por el crédito. Ya fuera de forma voluntaria y libre, ya inducida u obligatoria, los moriscos consumían créditos individual y colectivamente. En no pocas ocasiones, los moriscos - las aljamas, en realidad- habían sido obligados a cargarse con préstamos forzosos y a responder del pago anual de sus intereses a perpetuidad, sin posibilidad legal de amortizar la deuda y de quitar los censales, ya que estos -a su vez- constituían la garantía de beneficios eclesiásticos, fundaciones y obras pías ${ }^{126}$. En otras, sin embargo, los moriscos solicitaban crédito - sin descartar otras opciones- para adquirir bienes, mejorar el rendimiento de sus explotaciones o ampliar el volumen de sus actividades. Podían hacerlo de manera individual, junto con su esposa e hijos e -incluso- podían unirse varias familias para contraer un préstamo y garantizar con

126. Llorens RagA, Peregrín: «La morería de Segorbe. Rentas de su mezquita a fines del siglo XVI», Boletín de la Sociedad Castellonense de Cultura, Castellón de la Plana, 1973, XLIX-4, págs. 303-324. 
mayor solvencia su devolución con los intereses pactados. Los prestamistas -fueran quienes fuesen- confiaban en los moriscos $\mathrm{y}$, a poco que éstos tuvieran bienes con que responder de su devolución, no solían negarles el dinero. Para ellos, el decreto de expulsión fue - sin duda- la peor de las noticias. Ahora bien, si nos atenemos a la información que hemos podido reunir acerca del expolio de Segorbe, en modo alguno cabría afirmar que el extrañamiento de los moriscos fuera una tragedia para sus acreedores.

Comencemos - como hemos hecho antes- por establecer el volumen de la deuda de la que respondían los moriscos segorbinos. Para ello, además de los datos que ordinariamente se desprenden de los expedientes del expolio, poseemos el registro 10.122 de Maestre Racional, al final del cual aparecen cerca de 195 breves expedientes de reclamación resueltos por el comisario extraordinario Adrián Bayarte entre el 20 de julio de 1615 y el 3 de octubre del mismo año ${ }^{127}$. El contenido de estos expedientes es muy variado, aunque - por lo general- los asuntos que allí se abordaban eran los regulados por la Real Pragmática sobre las cosas tocantes al assiento general del Reyno de Valencia por razón de la expulsión de los moriscos y reducción de los censales, aprobada en Madrid por Felipe III y el Consejo de Aragón el 2 de abril de 1614 y publicada en Valencia el 15 del mismo mes y año ${ }^{128}$. Ayudado diligentemente por el notario Juan Bautista Queito y por el escribano Juan Chova, Bayarte -al tiempo que recorría a caballo toda la comarca - fue analizando caso por caso y comunicando su decisión por carta al administrador y baile de Segorbe Mateo Bosch y al clavario del expolio Joaquín Ayerve. Entre estos expedientes figuran las demandas presentadas por los acreedores de los moriscos expulsos, las complejas -en muchos casos-negociaciones entabladas por Bayarte para la satisfacción de los intereses y de la deuda pendiente, el cálculo de la misma a tenor de la reducción oficial del interés censal y -finalmente- la notificación de la resolución a la administración del expolio segorbino para que se pagaran los atrasos oficialmente reconocidos con las rentas disponibles.

Nos hemos servido tanto de la deuda reconocida por la administración del expolio desde el primer momento, cuanto de los expedientes revisados por Bayarte 6 años después para calcular que el capital adeudado por los moriscos segorbinos en el momento de su expulsión podía ascender a 434.862 sueldos y 4 dineros, es decir, a 21.743 libras, 2 sueldos y 4 dineros. Esta suma representaba casi 5 veces más -4'7 exactamente- que la cantidad prestada por los moriscos de la vereda de Segorbe durante la década inmediatamente anterior a la expulsión. Sumadas una y otra cantidad, es decir, las 21.743 libras de la deuda morisca y las 4.572 libras a que ascendían los créditos concedidos por moriscos a cristianos viejos, a la primera le correspondía una proporción del $82{ }^{\prime} 6 \%$ y a la segunda el $17^{\prime} 4 \%$.

127. ARV: Maestre Racional, exp. 10.122 (conjunto de expedientes sueltos). 128. Publicada en Valencia por Pedro Patricio Mey en abril de 1614 (10 fols). 
Capital censal del que respondían los moriscos segorbinos (Segorbe + Geldo + Navajas + Betxí + Cárrica) en el momento de la expulsión

\begin{tabular}{|c|c|c|c|}
\hline & Principales & $\%$ & Promedio \\
\hline Antiguo Patrimonio & $5.568 \mathrm{~s} .4 \mathrm{~d}$. & 1 '4 & \\
\hline Instituciones eclesiásticas y religiosos & 192.064 s. 2 d. & $44^{\prime} 1$ & 6.402 s. 2 d. \\
\hline Capítulo catedralicio & 23.546 s. 6 d. & & \\
\hline Beneficios (18) & 49.392 s. $6 \mathrm{~d}$. & & 2.744 s. $1 \mathrm{~d}$. \\
\hline Cartuja Valdecristo & 69.926 s. 8 d. & & \\
\hline Cofradías Sta. M M y S. Blas $^{\mathrm{a}}$ & 4.992 s. 3 d. & & 2.496 s. 2 d. \\
\hline Convento Esperanza & $11.684 \mathrm{~s}$. & & \\
\hline Hospital & 9.337 s. 9 d. & & \\
\hline Parroquia S. Juan (Valencia) & $9.600 \mathrm{~s}$. & & \\
\hline Religiosos (5) & 13.584 s. $6 \mathrm{~d}$. & & 2.716 s. $11 \mathrm{~d}$. \\
\hline Nobleza & $62.408 \mathrm{~s} .10 \mathrm{~d}$. & $14 ’ 3$ & $12.481 \mathrm{~s} 9 \mathrm{~d}$. \\
\hline Falcó de Belaochaga, Miguel & $2.760 \mathrm{~s}$. & & \\
\hline Falcó de Belaochaga, Pedro & $7.600 \mathrm{~s}$. & & \\
\hline Ferrer, Pedro & $3.160 \mathrm{~s}$. & & \\
\hline Gamir de Marrades, Francisca & 13.333 s. 4 d. & & \\
\hline Grau de Arellano, Luis Juan & 35.555 s. $6 \mathrm{~d}$. & & \\
\hline Marrades, Francisco & $i ? \dot{i} \cdot \dot{i} \cdot \dot{i} \cdot \dot{i} \cdot \dot{i}$ & & \\
\hline Particulares (39) & $174.821 \mathrm{~s}$. & $40 ’ 2$ & 4.482 s. 6 d. \\
\hline TOTAL & 434.862 s. 4 d. & & \\
\hline
\end{tabular}

Como puede apreciarse en el cuadro anterior, dos grandes sectores concentraban la mayor parte de la deuda censal contraída por los moriscos antes de la expulsión: las instituciones eclesiásticas - beneficiarias de legados, donaciones y fundaciones garantizadas con este tipo de renta ${ }^{129}$ - y un total de 39 particulares que habían confiado en la

129. Muchos de los beneficios eclesiásticos, fundaciones y donaciones a la iglesia se hallaban garantizados por censales de los que respondía colectivamente la Aljama del Arrabal de Segorbe. Este es el caso de los censos de la Cartuja, de la mayor parte de los censos de la Catedral y del Convento de la Esperanza, de una parte de los censos de la Cofradía de la Virgen María de la Seo y de buena parte de los beneficios eclesiásticos fundados en la iglesia-catedral de Segorbe. Entre éstos últimos, la Aljama había venido garantizando el de los santos Abdón y Senén, el del Altar Mayor o de la Natividad, el de Santa Ana, el de los dos santos Antonios, el de Santa Clara y Santa Eulalia, el de San Honorato y Santa Magdalena, el de María Santísima, el de las Once Mil Vírgenes y el de la Presentación. La aljama de los moriscos de Betxí, por su parte, abonaba anualmente una pensión de 206 sueldos para el beneficio de San Valero de Segorbe. Finalmente, diversos particulares moriscos habían concertado los censales que sostenían los beneficios catedralicios de San Andrés, Santa Bárbara, el llamado beneficio olim canonicato, el de San Jorge (ahora llamado del Alma) y una pequeña parte del beneficio de las Once Mil Vírgenes. 
solvencia y la laboriosidad de los moriscos. Ambos grupos se repartían el 84’3\% de la deuda censal y tanto uno como otro tenían comprometido en este tipo de operaciones crediticias más del $40 \%$ del capital censal prestado a los moriscos. El llamado censal del Antiguo Patrimonio apenas representaba un 1'4 de la deuda, mientras que la nobleza -grupo que sólo contaba con 6 acreedores- únicamente participaba del 14\% de la deuda. Los promedios de la deuda censal revelan -sin embargo- que los nobles habían prestado una media de 3 veces más dinero a los moriscos que los particulares -12.500 frente a 4.500 sueldos- y que sus principales representaban el doble poco más o menos de los de la iglesia -12.500 frente a 6.400 sueldos. Entre las instituciones religiosas, era la Cartuja de Valdecristo la que teóricamente más podía haber sufrido con la expulsión -con casi 70.000 sueldos de principal- seguida del capítulo catedralicio -23.500 sueldos- el Convento jerónimo de la Esperanza -11.700 sueldos- la parroquia de San Juan del Mercado de Valencia -9.600 sueldos- el hospital de Segorbe -9.300 sueldos-y los diferentes beneficios, cofradías y eclesiásticos que -como promedio-interesaban unos 2.500 sueldos cada uno de ellos en la deuda censal.

Este importantísimo volumen de deuda censal - cercano a las 22.000 libras-iba a tardar cerca de 7 años en ser reconocido en su totalidad. A decir verdad, sin embargo, la mayor parte de esta deuda fue asumida desde el primer momento -o casi- por la administración del expolio apenas sin objeciones, especialmente cuando se trataba de institutos religiosos ${ }^{130}$. El caso más notorio es el de la Cartuja de Valdecristo, a cuya comunidad abonó escrupulosamente el expolio todos los intereses adeudados desde la paga de Navidad del año 1609 en adelante ${ }^{131}$. También fue muy bien tratado el presbítero Diego Vidaure que -aunque tarde- recibió en 1612 cuatro anualidades y media de atrasos. En líneas generales, entre principios del año 1610 y finales de 1612, la administración del expolio reconoció una deuda censal cercana a los 300.000 sueldos, lo que representa un $67^{\prime} 8 \%$ de la deuda censal global. El resto hasta completar la totalidad de la deuda - descontando los casos dudosos y los que finalmente fueron rechazados- sería reconocido entre julio y octubre de 1615. La administración del expolio del Ducado de Segorbe - por su parte- casi siempre dispuso de dinero suficiente para abonar la práctica la totalidad de las pensiones adeudadas. La venta de los granos, hortalizas y algarrobas no cosechadas por los moriscos, el arrendamiento de las casas y las tierras abandonadas, la reserva de frutos pactada en los nuevos establecimientos enfitéuticos, las peitas y otros ingresos menores permitieron a los administradores del

130. El Marqués de Caracena puso todo su empeño en que la administración del expolio abonase con puntualidad los réditos garantizados con las propiedades de los moriscos expulsos a estas instituciones. Aunque no se conservan todas las órdenes de pago, sí hemos localizado algunas de las primeras: beneficio de Santa Ana y Capítulo de la Seo (Valencia, 4-V-1610), beneficios de Santa Cruz -San Honorato, en realidad-y Santa Magdalena, de la Once Mil Vírgenes y Hospital de la ciudad de Segorbe (Valencia, 18-V-1610), cuadernillo aparte, fols. 2 r-2 v, 18 r-18 v.

131. La orden para iniciar los pagos a la Cartuja fue dada en Valencia el 24 de abril de 1610 por Caracena. ARV: Maestre Racional, exp. 10.117, cuadernillo aparte, fols. 3 r-3 v. 
expolio del Ducado de Segorbe hacer frente a las obligaciones crediticias contraídas por la Aljama y los particulares moriscos antes de su expulsión.

\section{Capitales y pensiones censales abonadas por la administración del expolio segorbino entre 1609 y 1612}

\begin{tabular}{|c|c|c|c|c|}
\hline & Principales & $\begin{array}{l}\text { Intereses } \\
\text { anuales }\end{array}$ & $\begin{array}{c}\text { Realmente } \\
\text { Pagado hasta } \\
1612\end{array}$ & $\begin{array}{c}\text { Equivalente } \\
\text { en anuali- } \\
\text { dades }\end{array}$ \\
\hline Antiguo Patrimonio & 5.568 s. 4 d. & 278 s. 5 d. & 278 s 5 d. & 1 \\
\hline \multicolumn{5}{|l|}{$\begin{array}{l}\text { Instituciones eclesiásticas } \\
\text { y religiosos }\end{array}$} \\
\hline Capítulo catedralicio & 13.813 s. $2 \mathrm{~d}$ & $1.036 \mathrm{~s} .3 \mathrm{~d}$ & 2.581 s. 4 d. & 2,5 \\
\hline Beneficios (9) & $37.161 \mathrm{~s}$. & 2.610 s. 9 d. & 6.896 s. 3 d. & 2'6 \\
\hline Cartuja Valdecristo & 69.926 s. 8 d. & 3.544 s. 5 d. & 14.217 s. $1 \mathrm{~d}$. & 4'0 \\
\hline Cofradías Sta. $\mathrm{M}^{\mathrm{a}}$ & 3.484 s. 6 d. & 261 s. 4 d. & 646 s. 5 d. & $2 ' 5$ \\
\hline Convento Esperanza & $11.584 \mathrm{~s}$. & $900 \mathrm{~s}$. & $2.250 \mathrm{~s}$. & $2 ' 5$ \\
\hline Hospital & 9.337 s. 9 d. & 700 s. 4 d. & 1.826 s. 8 d. & 2'6 \\
\hline Parroquia S. Juan (Valencia) & $9.600 \mathrm{~s}$. & $720 \mathrm{~s}$. & $1.080 \mathrm{~s}$. & $1 ' 5$ \\
\hline Religiosos (1) & 3.451 s. 2 d. & 258 s. 10 d. & 1.145 s. $1 \mathrm{~d}$ & 4,4 \\
\hline \multicolumn{5}{|l|}{ Nobleza } \\
\hline Ferrer, Pedro & $3.160 \mathrm{~s}$. & 237 s. 6 d. & $475 \mathrm{~s}$. & 2 \\
\hline Gamir de Marrades, Francisca & 13.333 s. 4 d. & $1.000 \mathrm{~s}$. & $2.000 \mathrm{~s}$. & 2 \\
\hline Grau de Arellano, Luis Juan & 35.555 s. 6 d. & 2.666 s. $8 \mathrm{~d}$. & 6.193 s. 2 d. & 2,3 \\
\hline Particulares (10) & 79.004 s. 5 d. & 5.917 s. $1 \mathrm{~d}$. & 18.456 s. 9 d. & 3'1 \\
\hline TOTAL & 294.980 s. 1 d. & 20.130 s. 7 d. & 58.046 s. 2 d. & 2'9 \\
\hline
\end{tabular}

Ahora bien, ni todos los pagos se verificaron de manera regular -en cuantía y/o plazo- ni todos los acreedores fueron tratados del mismo modo. Curiosamente, quienes salieron peor parados fueron 3 nobles $^{132}$ y el clero de la parroquia de San Juan del Mercado de Valencia, probablemente porque ni ellos ni sus procuradores residían en Segorbe, ni estaban - por tanto- en disposición de presionar a los administradores del expolio en la misma medida que los acreedores segorbinos. Los 10 particulares cuyo derecho a percibir indemnizaciones del expolio fue reconocido entre 1610 y 1612 -sin ir más lejos- recibieron la integridad de las 3 anualidades adeudadas, y las mayor parte de instituciones eclesiásticas y los religiosos percibieron una cantidad de dinero equivalente a 2'5 anualidades.

En definitiva, si hacemos abstracción de los casos más llamativos y contemplamos una panorámica de conjunto, es menester subrayar que el reconocimiento de casi el $70 \%$ de este tipo de deuda censal a lo largo de los 30 meses inmediatamente posteriores a la expulsión y el abono -en el mismo plazo- de las prácticamente 3 anualidades acumuladas hasta entonces -bien que reducidas al 5\% de interés- dista mucho de cons-

132. D. ${ }^{a}$ Francisca Gamir de Marrades, D. Pedro Ferrer y D. Luis Juan Grau de Arellano. 
tituir esa especie de catástrofe convertida en lugar común de la historiografía morisca y valenciana ${ }^{133}$. Nadie niega que los acreedores pasaran apuros -unos más que otros, claro. Pero todos aquellos que pudieron demostrar la legitimidad de sus derechos sobre el expolio del Ducado de Segorbe acabaron cobrando lo que se les debía y -aunque renegociadas a la baja-continuaron percibiendo las anualidades que les correspondían.

133. RegLÀ CAMPISTOL, Joan: «La expulsión de los moriscos y sus consecuencias en la economía valenciana», Estudios sobre los moriscos, Barcelona, 1974, págs. 219-243. 